This is an electronic reprint of the original article. This reprint may differ from the original in pagination and typographic detail.

Author(s): Lehkonen, Heikki; Heimonen, Kari

Title: Democracy, political risks and stock market performance

Year: $\quad 2015$

Version:

Please cite the original version:

Lehkonen, H., \& Heimonen, K. (2015). Democracy, political risks and stock market performance. Journal of International Money and Finance, 59, 77-99.

https://doi.org/10.1016/j.jimonfin.2015.06.002

All material supplied via JYX is protected by copyright and other intellectual property rights, and duplication or sale of all or part of any of the repository collections is not permitted, except that material may be duplicated by you for your research use or educational purposes in electronic or print form. You must obtain permission for any other use. Electronic or print copies may not be offered, whether for sale or otherwise to anyone who is not an authorised user. 


\title{
Democracy, political risks and stock market performance
}

\begin{abstract}
This study examines the impacts of democracy and political risk on stock market. Using annualized panel data for 49 emerging markets for 2000-2012 we find evidence that democracy and political risk do have impact on stock market returns and the relationship between democracy and political risk is parabolic i.e., there is a threshold level of democracy after which political risk begins to decline. Our also results suggest that decreases in political risk lead to higher returns.
\end{abstract}

JEL classification: G15, G12, F52

Keywords : Democracy, Political risk, Emerging markets, Stock market performance 


\section{Introduction}

There are many real life events which propose that stock market performance and political stability might be strongly related. However, there exists hardly any empirical research testing this relationship. The beginning of 2011 witnessed the Arab Spring, which consisted of large prodemocracy demonstrations against dictatorships in the MENA region that even escalated to civil war in Libya. The riots began in Tunisia and spread to Egypt, Libya and several other countries leading to political instability in the entire area. Because the unrest seemed to be transmitted from one country to another, investors became more and more worried; for example, on January 27 , 2011, Egypt's benchmark index, the EGX 30, dived 10\% and even the world's major markets in the USA, Europe and Asia tumbled because the protests were expected to continue moving to other oil producer countries in the area. The unrest in Egypt lasted for all of 2011 because the Egyptian military, which seized control of the government after the revolution, refused to release power to the democratically elected government. Between January 3, 2011 and January 2, 2012, the EGX 30 index lost almost $50 \%$ of its value, dropping from 7073.12 to 3679.96 .

In 2006, after several months of political crisis, the Thai military ousted the elected prime minister from power and, together with the ruling elite, appointed a new prime minister in 2008 to lead the country during the next several years, which consisted of more-or-less violent demonstrations between the supporters of the ousted prime minister and his opposition. The political instabilities led foreign investors to reduce their exposure to the Thai market, dragging down prices for a period; however, because the demonstrations remained peaceful, the markets calmed and began to rise.

Latest examples of the relationship between unstable political environment and stock market performance are offered by the political turmoil in Ukraine in 2014, which led to conflict with Russia and collapsed the Russian stock market, and the demonstrations for democracy in September 2014 in Hong Kong which had negative impacts on Hong Kong stock market. 
The effects of political risk have been found to be statistically significant in emerging stock markets (see, e.g., Erb, Harvey and Viskanta (1996a), Diamonte, Liew and Stevens (1996) and Perotti and van Oijen (2001)). Moreover, the ever increasing international capital flows could reinforce the impact of political turmoil on stock markets. Lensink, Hermes and Murinde (2000) support this by providing evidence that an increase in political risk leads to increase in capital flight. Although these studies incorporated democracy as a part of their political risk component, there has not been a study to our knowledge that examined whether democracy can affect the behavior of the stock markets ${ }^{1}$. This study aims to fill the gap by investigating the effects of democracy and political risks on the stock market performance for a set of emerging markets. Several studies on democracy and political risk (see, e.g., Gleditsch and Hegre (1997); Hegre, Ellingsen, Gates, and Gleditsch (2001); Reynal-Querol (2002a,b); and Rock (2009) and their references) have observed that the semi-democracies are more prone to conflicts, corruption and other political risks than full democracies and autocracies. This reflects that the semi-democracies, unlike full democracies and full autocracies, have not yet established strong institutions that might prevent protests and other anti-government activities, which makes these countries more vulnerable to political instabilities. Thus, it might be argued that democratization initially increases political risk and reduces it only after a certain threshold level of democracy has been reached. For this to hold, democracy's relationship with political risk could be described by a U-curve that indicates that the countries at the ends of the curve have smaller political risks than the countries in the middle (see Figures 1 and 2, in which the $\mathrm{x}$-axis presents the level of democracy and the $\mathrm{y}$-axis represents the political risk level for several emerging markets). The quadratic polynomial in the figures describes this nonlinear relationship between democracy and political risk: polrisk $=\beta_{0}+\beta_{1}$ dem $+\beta_{2}$ dem ${ }^{2}$, where polrisk denotes the countries' political risk, dem represents the democracy level and dem $^{2}$ its square. It is notable in this that although the coefficient $\beta_{1}$ is negative, $\beta_{2}$ is positive, which

\footnotetext{
${ }^{1}$ However, institutions related to democracy and their stock markets have been studied. The relationship between democratic elections and international stock returns has been examined before by Foerster and Schmitz (1997); Panzalis, Stangeland and Turtle (2000); and Bialkowski, Gottschalk and Wisniewski (2008), for example.
} 
indicates that, after passing a threshold level, the higher levels of democracy decrease political risk, in this functional form.

\section{[Insert Figures 1 and 2 here]}

The main question this study aims to answer is the following: Do democracy and political risks have effect on stock market performance or are the markets immune to the political environment? As a by-product of our analysis, we also contribute to the political risk sign paradox (see below and Section 2.3) and identify several determinants of emerging stock market returns.

There is no commonly accepted theory relating democracy to stock market returns; thus, the issue between their relationship is mainly empirical. On the one hand, consistent with ICRG (International Country Risk Group) classifications, the lack of democracy, or democratic accountability, is part of the total political risk; thus, it should be priced in share prices together with other risks, following Erb et al. (1996a). On the other hand, Perotti and van Oijen (2001) find that political risk has a positive sign that indicates that politically safer countries have higher excess returns than markets with more political risk; supporting this, Diamonte et al. (1996) posit that portfolios that experienced decreases in their political risk also produced larger returns than portfolios with increased political risk.

It could also be argued that democracies are generally associated with better institutions, such as the protection of private property and better enforcement of laws and regulations. However, because democracies are subject to frequent change of government officials, they might be considered as politically more unstable than autocracies with respect to governmental stability and political predictability. Conversely, this attribute might indicate that democracies are better able to adjust to political and economic environments. Semi-democracies, on the other hand, 
might be lacking the growth supporting effects of democracy (better institutional environment), but they suffer from its negative effects on stability (increased political uncertainty, corruption).

Aggregate stock market returns are fundamentally related to economic growth. The evidence for the effects of democracy on economic growth are far from unanimous, however. Among others, Tavares and Wacziarg (2001) posit that democracy has both positive and negative effects; after all the effects are accounted for, the total impact is slightly negative. Persson and Tabellini (2007), in turn, find that democracy has positive effects on economic growth. Acemoglu, Johnson, Robinson and Yared (2008) show that, after controlling for factors affecting both democracy and economic growth, the relationship between democracy and growth disappears. Instead, the authors argue that the cross-country correlation between income and democracy reflects only the common development paths of political and economic environment. To sum up, Docouliagos and Ulubasoğlu (2008) provide meta evidence from 84 democracy-growth studies that democracy net effect on economy is not detrimental. Moreover, Rodrik and Wacziarg (2005) indicate that the even the process of democratization comes at no costs to growth with likely boost in growth and reduction in economic volatility. Further evidence on the negative effects of democracy on volatility of growth is provided in Mobarak (2005). However, regardless of the connection between economic growth and stock market performance, it is possible that democracy and political stability might continue to have a direct impact on stock market performance over and above their impact on economic growth.

We utilize two different sources for measuring democracy, the Polity variable from Polity IV and the democratic accountability subcomponent from the International Country Risk Guide's (ICRG's) political risk component. Political risk itself is quantified by the ICRG's political risk composite index, excluding Democratic accountability (more information on these indices can be found from Section 2 and Appendix 1). In addition to the composite index, we study its subcomponents individually to discover which risks have the most significant effects on stock 
market performance. These subcomponents are Government stability, Socioeconomic environment, Investment profile, Internal conflicts, External conflicts, Corruption, Military in politics, Religious tensions, Ethnic tensions, Law and order and Bureaucracy quality. We also examine two risk vectors that aggregate several political risk subcomponents. The first is Conflicts and tensions from Internal and External conflicts, in addition to Religious and Ethnic tensions. The second is Quality of institutions, which incorporates Corruption, Law and order and Bureaucracy quality.

As our core sample, we study annual data on 49 emerging markets for the years 20002012. Using a large set of control variables for both local and global factors, we aim to capture both the effects of democracy and its interaction with political risk by using the following two methods: pooled OLS with clustered standard errors and system GMM model by Blundell and Bond (1998).

Our results are partly mixed and emphasize the use of several measures of democracy. While icrg finds consistent and statistically significant relationship between democracy and its squared term with the world market adjusted local returns, polity does not support this. However, consistent with Perotti and van Oijen (2001), we report the positive relationship between political risk and returns indicating that - somewhat counter intuitively - decreases in political risks are shown to be related to higher returns. In addition, the interaction effects between the icrgdemocracy level and political risk are negative, whereas those of squared democracy and political risk are positive. Of the control variables, logarithm of the GDP per capita, exchange rate changes, development of the local banking and financial sector and the global inflation rate affect emerging market returns ${ }^{2}$.

In addition to using two estimation methods and two measures for democracy, we also test the robustness of the results with several ways in Appendix 2: by altering the observation periods; by using the mean of our democracy measures to quantify democracy; by different estimation method; and by excluding markets from our core sample data based on their political

\footnotetext{
${ }^{2}$ We also studied whether democracy and political risks could be related to stock market crises, but find no significant results.
} 
risks and democracy level. The effects of the interaction terms remain rather consistent in our estimations.

The rest of the study is organized as follows. Section 2 presents our data and the descriptive statistics. Section 3 describes our estimation strategy, and section 4 reports the estimation results. Section 5 concludes.

\section{Data}

The governmental systems and the democracy level of emerging markets varies along the entire autocracy-democracy spectrum from more centrally led systems, such as China, to full democracies, such as Israel, when compared with the more developed countries (that are all closer to full democracies). Because of this and because it has been noted in the previous studies (Diamonte et al. (1996), Erb et al. (1996a), Bilson et al. (2002)) that emerging markets are more vulnerable to political instabilities than developed markets, we concentrate our analysis on emerging stock markets. As our core dataset, because of our estimation strategy and data availability, we utilize an unbalanced panel data on 49 developing countries over the 2000-2012 period. In addition, for the robustness tests and the crisis study, we extend our data to begin in 1988, with several different starting periods, aiming to provide a comprehensive picture of the developing stock markets and their macroeconomic and political environments. Table 1 summarizes the descriptive statistics for our variables.

\section{Table 1 here}

\subsection{Stock market performance}

The fact that most of the emerging markets were founded and opened their stock markets to foreign investors at the beginning of the 1990s limits both the number of suitable markets and the 
observation period. Our sample period ends in 2012 and has the following six different starting years: 1988 (Argentina, Brazil, Chile, Greece, Indonesia, Jordan, Malaysia, Mexico, Philippines, Portugal, South Korea, Thailand and Turkey), 1993 (China, Colombia, India, Israel ${ }^{3}$, Pakistan, Peru, Poland, South Africa and Sri Lanka), 1995 (Czech Republic, Egypt, Hungary, Morocco and Russia), 2003 (Croatia, Estonia, Kenya, Nigeria and Slovenia), 2005 (Tunisia), 2006 (Bahrain, Bulgaria, Kazakhstan, Kuwait, Oman, Qatar, Romania, Saudi Arabia and United Arab Emirates), 2007 (Ukraine and Vietnam), 2009 (Ghana, Jamaica, Lithuania and Trinidad \& Tobago) and 2010 (Bangladesh). For each of the above-mentioned markets, we take the MSCI Standard Total Return index, which combines price performance with reinvested dividend payments, and use the MSCI World index to measure the general development of the world's stock markets. All the price data are denominated in the U.S. dollars. Because the political environment - the main object of interest in this study - is rather rigid, the data frequency is chosen to be annual. We adjust local returns to global returns by regressing the local returns on the world returns over the full sample period and using the 12-month averages of residuals as our dependent variables. As Table 1 shows, local returns have been positive in most of the markets. However, for countries with shorter observation periods, the effects of the global financial crisis of 2007-2009 are visible as negative average returns.

\subsection{Democracy}

Democracy is a complex political and social phenomenon and as such the concept is challenging to measure accurately. To measure democracy, its attributes must be understood. These include - at the least - free and competitive elections with open political participation and constraints on representatives, in addition to their accountability to their electorate. There has been some criticism of the typically used measures of democracy (Munck and Verkuilen (2002) provide a

\footnotetext{
${ }^{3}$ Although MSCI Barra has announced that it will classify Israel as a developed country as of May 2010, we include it in our dataset because it was an emerging market during most of our sample period.
} 
comprehensive study of the conceptualization, measuring and aggregating problems related to the measures), and we acknowledge that neither of the measures we use to quantify democracy is perfect. Furthermore, Casper and Tufis (2003) warn that even highly correlated democracy measures can produce different results; thus, researchers must justify their measurement choices carefully. Therefore, to take into account as many aspects of democracy as possible and to address data selection issues, we use two different measures for democracy: the Polity index of Polity IV and the democratic accountability index from the Political Risk Service, published in ICRG. Both of these measures are available for the entire sample period for all of our studied markets. The data from Polity IV are available for free, whereas ICRG data are not.

Our first measure of democracy, the Polity index, polity, is the difference between Polity IV's Democracy and Autocracy indices ranging from -10 (full autocracy) to 10 (full democracy). Polity IV's Democracy index measures the competitiveness and openness of executive recruitment, constraints on chief executive representatives and the institutions and procedures that allow citizens to participate in politics. The values range from zero to ten, and a higher rating implies higher levels of democracy. Polity IV's Autocracy index is constructed similar way to the Democracy index and is based on the competitiveness of political participation, the regulation of participation, the openness and competitiveness of executive recruitment and the constraints on the chief executive. Its values range from zero to ten, with a higher value denoting higher autocracy. ${ }^{4}$ Although Munck and Verkuillen (2002) list several strengths of the polity index, they also argue that the index is too minimalistic in its measurement of democracy because it lacks one important component of political participation (the right to vote) and suffers from redundancy issues in some of its measures and aggregates its components too simply.

As a second measure of democracy, we use the Democratic accountability index, icrg, from ICRG. The data measure the level of democracy by examining governance on the basis of how

\footnotetext{
${ }^{4}$ For more information about the Polity IV Project, the Polity index and user manual can be found at http://www.systemicpeace.org/inscr/inscr.htm
} 
free and fair elections are, the presence of (opposition) political parties, the existence of legal protection of personal liberties and government accountability to its electorate. The index ranges from one to six, with the higher number denoting better democracy. ${ }^{5}$

We also considered one more widely used democracy variable (used, for example, by Barro (1999), Acemogly et al. (2008) and Asiedu and Lien (2011)), the political rights metric by Freedom House, which does not explicitly measure democracy or democratic performance. Instead, it aims to measure rights and freedoms that are related to democracy with a list of 10 questions that range from whether there are free and fair elections to the right to vote and form political parties, whether the opposition has any role to play in government and whether the freely elected government actually holds power, is free of corruption and is accountable for its actions ${ }^{6}$. The highest ranking of one indicates the highest degree of freedom whereas seven denotes the absence of political rights. Munck and Verkuillen (2002) criticize the usefulness of the index because it includes too many components (some of which are not even relevant to democracy), the measuring and coding of the components is unclear and the aggregation of the components is overly simple. The most serious problem with the Freedom House data in our case is, however, that it incorporates several of the subcomponents (government stability, corruption, foreign and domestic military involvement in politics and ethnic tensions) of our political risk component index into its democracy index; thus, using the Freedom House data as our democracy measure might contaminate our regressions. Freedom House also provides an index for civil liberties but this works no better for us than the political rights index because it includes subcomponents such as socioeconomic conditions, external and internal conflicts, law and order and ethnic tensions. Thus, we exclude the Freedom House's democracy measurement from our dataset.

\footnotetext{
${ }^{5}$ More information about ICRG's democratic accountability index and other risk components can be found at http://www.prsgroup.com/ICRG_Methodology.aspx

${ }^{6}$ Complete checklist questions and guidelines for the Freedom House political rights data can be found at http://old.freedomhouse.org/template.cfm?page=351\&ana_page $=364 \&$ year $=2010$
} 
To ease the comparison between these measures, we follow Barro (1999), Acemogly et al. (2008) and Asiedu and Lien (2011) and normalize the measures between zero and one, with the higher number indicating a more democratic country. Although both of our democracy variables measure slightly different aspects of democracy, their correlation is high at 0.74 . However, as Table 1 shows, polity presents an average value of 0.64 for Pakistan, whereas icrg measures its democracy at a level of 0.36 . Conversely, for Bahrain, polity shows only 0.08 , whereas icrg's average democracy value is 0.43 . To account for these differences in the democracy variables, we also consider the average of these measures as our democracy variable as a robustness check.

\subsection{Political risk}

Political risk does not have one single definition, although it may generally be understood as the risk of unanticipated transformations in the national and international business environment as a result of political changes, such as sudden changes in taxation laws and government policies, foreign and domestic conflicts, in addition to the quality of the governing institutions. Quantifying political risk is difficult, although the events related to it are clearly visible. We rely on ICRG's Political Risk components, which provide a means of assessing the political stability of the countries on a relative basis. The index has been widely used e.g. by Diamonte et al. (1996), Erb et al. (1996a), Bilson et al. (2002), Bekaert et al. (2011) and Asiedu and Lien (2011) to study foreign direct investment and stock market behavior. ICRG's index was originally designed to analyze potential risks to international business operations but as share-issuing companies face identical risks, the measure can also be used to study stock market behavior. The ICRG index is constructed using subjective staff analysis of available information; in that sense, it can be considered a forward looking measure. Thus, it may be suitable for stock market analyses because share prices reflect expectations of future income. The index is composed of 11 components, including Government stability, External conflicts, Internal conflicts, Ethnic tensions, Military in politics, Religious 
tensions, Socioeconomic conditions, Investment profile, Bureaucracy quality, Corruption and Law and order (in addition to Democratic accountability as the twelfth, but we study it separately) ${ }^{7}$. The political risk rating is performed by assigning risk points to these components with minimum points being zero and maximum depending on the maximum weight that the particular component is given in the overall political risk assessment, which ranges from 4 to 12 , with higher points denoting lower risks. In addition to the political risk composite index, we build two additional risk ratings from its sub-components. The conflicts and tensions component sums the external and internal conflicts with the ethnic and religious tensions, on the one hand, whereas our quality of institutions component follows Bekaert et al. (2011) and sums corruption, law and order, and bureaucratic quality. As with democracy measures, the data are normalized to lie between zero and one.

According to the standard portfolio model, investors demand higher return for higher risk; thus, it would be expected that our political risk components would have a negative effect on excess returns, which is actually the case with some of the previous results from Erb et al. (1996a) and Bilson et al. (2002). However, Perotti and van Oijen (2001) find a significant positive relationship between political risk and excess returns (decreases in risks lead to higher returns), which is further supported by the results from Diamonte et al. (1996) and Erb et al. (1996a) that state that emerging countries receiving upgrades to their political risk profile also receive higher returns than those being downgraded. This setting creates a political risk sign paradox because it is unclear what sign the political risk and democracy components should take. One of our intensions is to examine this paradox and study whether political risk is even a significant determinant of returns.

It might be argued that the democracy level is highly correlated with political risks. The political risk component includes a measure for Military in politics, for example, which measures the military's presence (or absence) in the governance system. Because democracies should not have any military presence in their governance, it could be expected that the correlation

\footnotetext{
${ }^{7}$ More accurate definitions of each of these terms are provided in Appendix 1 Table 1.
} 
between these two is close to 1 . To account for possibly multicollinearity suspicions, we calculate the pairwise correlations between our democracy measures and the political risk component - in addition to its subcomponents - and report these in Table 2. Correlation between democracy and political risk differs slightly between the democracy measures but is not very high (polity: 0.0925, icrg: 0.2394). Of the individual subcomponents, Bureaucracy quality has the highest positive correlation, which is followed by Corruption, Military in politics, Religious tensions and Investment profile. Naturally, Government stability has negative and rather low correlation with democracy because of elections. In general, however, the correlations in our basic setting are not too high to affect the estimation results.

\section{Table 2 here}

\subsection{Control variables}

Because we are studying return data with yearly frequency, the stock prices compress a large amount of information. We must control changes in both the financial and economic environments in our econometric framework. A significant amount of literature has previously studied the effects of macroeconomic factors and their relationship to equity returns (see e.g., Chen et al. (1986), Flannery and Protopapadakis (2002) and Rapach et al. (2005) and references therein) and has found monthly evidence, for example, that inflation, industrial production, term spread and interest rates are priced factors on the U.S. and other developed markets. However, because emerging markets do not report or do not possess some of these factors that are typically used, our control variables dataset choice is partly dictated by the availability of the reliable data. We aim to control both domestic and foreign factors and capture the countries' current level of economic development with a logarithm of GDP per capita in the U.S. dollars and annual GDP growth; rate the macroeconomic uncertainty of the economy with inflation measured with a GDP deflator; study the markets' relationship to changes in industrial activity with the change in industrial production; and use the 
narrow money growth (M1) and broad money growth (M2) metrics to measure the financial development of each country. We also include the exchange rate with the U.S. dollar to measure the foreign exchange exposure for each currency and proxy the stock market openness with the ratio of market capitalization to GDP. To capture the level of banking sector development we include a variable for domestic credit to private sector as a percent of GDP to our dataset and use the equity markets turnover to GDP ratio to proxy market liquidity.

Our global factors aim at capturing fluctuations on the world business cycle and include world inflation, changes in oil prices, world industrial production, the U.S corporate bond spread (Moody's Baa minus Aaa bond yields) and the term-structure spread (U.S. 10-year bond yield minus 3-month U.S. Treasury bill rate).

With the exception of exchange rates, industrial production and world factors, which are provided by Datastream, and the default spread, which is provided by the Federal Reserve Bank of St. Louis, all of the other control variables are obtained from the World Bank's World Development Indicators. See Appendix 1 Table 1 for details.

\section{Estimation methods}

To capture the effects of democracy and political risk on stock market performance, we use two different methods; we begin with a pooled regression (clustering the standard errors across countries) and continue with system GMM, a linear dynamic panel data model that is designed for short, wide panels. It can be used for unbalanced panels and to avoid the dynamic panel data bias in which the models contain unobservable panel-level effects that are correlated with a lagged dependent variable and render standard errors inconsistent. Model also accommodates multiple endogenous variables by using internal instruments, which makes it a particularly attractive alternative to finding external instruments that remain valid and robust across all panels. 
System GMM is a GMM-based estimator method based on the work of Arellano and Bond (1991) and was developed by Arellano and Bover (1995) and by Blundell and Bond (1998). The original Arellano-Bond estimator takes the first difference of the data and uses the lagged values of the endogenous variables as instruments. That is why it is often referred to as the difference estimator. Arellano and Bover (1995) note, however, that the lagged levels make poor instruments for first differences, particularly if the variables are close to the random walk; thus, they formulated the basis for a new, more efficient estimator, the system GMM, which gained its final form (and the conditions under which the estimator is valid) in Blundell and Bond (1998). System GMM avoids problem of poor instruments by introducing additional moment conditions and Hayakawa (2007) has shown theoretically that system GMM is less biased in small samples than difference GMM. However, Roodman (2009) warns that the downside of both of the estimators and particularly of the system GMM - is that they use too many instruments, which may give a false sense of certainty because a large number of internal instruments can over-fit the endogenous variables and weaken the Hansen tests for instrument validity. This problem arises when the number of time observations in the dataset increases, in particular. Moreover, Bun and Windmeijer (2010) have shown that the weak instrument problem may be problematic also for the system GMM approach. Even more criticism of the system GMM is aimed at its requirements. For system GMM to be valid, both the country-fixed effects and omitted variables must be orthogonal to the lagged differences of the right hand side variables that are used as instruments for the level equation. Because neither of these assumptions can be tested, Hauk and Wacziarg (2009) have concluded in their Monte Carlo study that an even larger problem than the weak instruments of the system GMM, is the validity of its moment conditions, which leads to some bias in its results. Despite its shortcomings, because the system GMM can handle the close-to-random-walk stock returns and small samples better than difference GMM, it is used as our main method in the formal econometric tests. 
System GMM estimation procedure assumes that there is no autocorrelation in idiosyncratic errors. Thus, for each regression, we test for autocorrelation and the validity of the instruments and report the p-values for the test for second order autocorrelation and for the Hansen (1982) J-test statistic for overidentifying restrictions. However, as Roodman (2009) notes, the Hansen's test statistic loses power when the number of instruments is large relative to the crosssection sample size (here, the number of countries). A sign of this is a p-value of 1.000 for the Hansen J-statistic. To avoid this, the typical rule of thumb is that the number of instruments, $i$, should be less than the number of the cross section sample size, $n$, i.e., the instrument ratio $r=n / i$ should be more than one. When $r<1$, the assumptions underlying the dynamic panel data models may be violated. Furthermore, a low ratio between sample size and instruments raises the susceptibility of the estimates to a Type 1 error, i.e., significant results are produced even though there is no underlying association between the variables involved. The simplest solution to this problem is to reduce the instrument count. We use two methods to accomplish this. Because the instrument number increases significantly with the length of the sample period, we limit our data sample to begin in the year 2000 and limit the number of lagged levels to be included as instruments by collapsing the instrument set as described by Roodman (2009). However, because it is not clear that $n=i$ really is a threshold level for reliable results, often we present the results for both the limited and unlimited instrument sets. In the robustness regressions, we also study different sample periods.

Roodman (2009) also makes an important point that researchers should not interpret the results of the autocorrelation test and Hansen's test based on the conventional significance levels of 0.05 or 0.10 . These levels, although useful for defining the significance of the coefficient, are not appropriate when trying to exclude specification problems, which are based on not rejecting the tests. Thus, when the p-value obtains a value only slightly higher than 0.10 , this should not be considered as strong evidence for the model. 
As our basic estimation method, we use the two-step GMM estimator with Windmeijer (2005) correction in our estimations because it is asymptotically efficient and robust to heteroskedasticity. However, as a robustness test, we also estimate the results with a robust one-step estimator.

\section{Benchmark regressions}

This section studies the following question: Does democracy have any effect on stock market performance? The economic reasoning of the equity market dynamics stems loosely from the APT theory. As Equation (1) - the basis of our work - presents, we estimate the impacts of democracy and political risk on stock market performance controlling for a large number of economic and financial variables that we believe to be important for the stock market performance.

$$
\begin{gathered}
R_{i t}=\beta_{0}+\beta_{1} \text { dem }_{i t}+\beta_{2} \text { dem }_{i t}^{2}+\beta_{3} \text { polris }_{i t}+\beta_{4} \text { dem }_{i t} * \text { polrisk }_{i t}+\beta_{5} \text { dem }_{i t}^{2} * \text { polrisk }_{i t} \\
+\beta_{6} R_{i t-1}+\sum_{j=1}^{J} \gamma_{j} Z_{i j t}+\theta_{i}+\varepsilon_{i t}
\end{gathered}
$$

where $i$ refers to markets; $t$ to time; $\theta_{i}$ is the country-specific effect; $R_{i t}$ is the world market adjusted return of market $i$ at time $t$; dem is a measure of democracy and $d e m^{2}$ its square; polrisk refers to different political risks; dem $*$ polrisk and $d e m^{2} *$ polrisk are the interaction terms; $Z_{i j t}$ is a control variables vector comprising of all other potential covariates; and $\varepsilon_{i t}$ is an error term that captures all other omitted variables, with $E\left(\varepsilon_{i t}\right)=0$ for all $i$ s. In effect, we are estimating the emerging stock market integration with respect to world returns as a by-product. If the emerging stock markets would be completely integrated $\beta_{1}=\beta_{2}=\beta_{3}=\beta_{4}=\beta_{5}=\gamma_{j}=0$ should hold, i.e., global factors would explain all the movements in the returns. The previous studies (e.g., Bekaert (1995), Erb et al. (1996b) and Bekaert et al. (2011)) have indicated that the political factors, in particular, might be of importance for market segmentation. 
In all of these forms, the lagged value is included to capture the possible persistency of the left-side variable and the mean-reverting dynamics. Our main interest, however, is in the parameters, $\beta_{1}, \ldots, \beta_{5}$, which measure the effects of democracy, political risk and their interactions on stock market performance.

\subsection{Variables affecting emerging stock market performance}

Because we have several highly correlated financial, political and economic variables, an estimation of the full model will generate a large amount of insignificant regressors that increase the number of instruments and needlessly inject noise into the estimated model. Thus, our aim is to reduce the number of variables into a more manageable set that best explains the variation in integration. In this task, we follow Bekaert et al. (2011) and Bekaert et al. (2014) and employ general-to-specific algorithm, explained in Hendry and Krolzig (2005). The algorithm constitutes of a process that eliminates variables with coefficient estimates that are not statistically significant over multiple steps. Concretely, we begin by estimating Equation (1) with all variables. We then eliminate the least statistically significant variable by using a significance threshold of $15 \%$. The use of relatively high significance levels reflects the preference of keeping a model with some useless regressors instead of eliminating any important variables. We continue step-by-step estimating the model and excluding the individual variables - simultaneously testing at every step whether an already excluded variable should be included again - until we arrive at a final model specification. However, we make few exceptions in the selection algorithm and leave the previous returns to the model; because we are concentrating on democracy, political risk and their interaction terms, we do not eliminate these variables either, although they might be insignificant.

\subsubsection{Effects of democracy and political risk}


We begin by studying the direct effects of democracy and political risk on stock market performance by estimating Equation (1) without the squared term $\mathrm{dem}^{2}$ and the interaction terms dem $*$ polrisk and dem $^{2} *$ polrisk. We present the results for all of our control variables and collapsed instrument set in Table 3 using the polity index as our democracy measure in columns (1), (3) and (5); and icrg in columns (2), (4) and (6). The columns (1) and (2) in Table 3 report the estimation results from pooled OLS, whereas columns (3)-(6) are from system GMM. Roodman (2009) provides examples and argues that the high number of instruments can generate both invalid results and can lead to the weakening of the Hansen's test statistic. Thus, we report the results for both, the full instrument set (columns (3)-(4)) and for the limited instrument set (columns (5)-(6)). The dependent variable in all the estimations is the world market adjusted returns.

\section{Table 3 here}

As shown, the signs and sizes of the coefficients remain rather similar across the estimations but the significance levels differ. However, for both, political risk and democracy, the sign is positive indicating that improvements in political risks and democracy lead to higher returns. However, while the coefficients of political risk are significant in almost every case, the estimates for democracy are significant in only three of the six estimations.

Of the local variables, exchange rate changes and domestic credit supply to the private sector (banking sector development) both have negative signs, which indicates that appreciation of the local currency and increases in the credit supply would lead to smaller local returns. Moreover, financial market development, measured by the growth in broad money supply (M2), market capitalization and turnover, has a consistent and positive effect on returns. It is also found that the economic development measured by logarithm of GDP per capita has a negative effect on returns. 
World inflation is the only global variable that is consistently significant and negative across all the estimations, which indicates that increases in global price levels negatively affect emerging market returns. For pooled OLS, together with constant, also world industrial production (positive) and term spread (negative) have statistically significant coefficients but these are excluded from the final system GMM models.

At the end of the table, we report observation numbers and the coefficient of determination for pooled OLS, in addition to the numbers of instruments and the instrument ratios for the dynamic panel data models. In addition, we report the p-values for the AR(2) test and Hansen's J test. The former indicates that the assumption of no serial correlation in error term is valid for all of our estimations, whereas the latter examines the validity of our instruments and does not reject our results. All the other tests are passed with $10 \%$ level, except the AR(2) test for models (5) and (6). Thus the result of these models should be treated with some caution.

\subsubsection{Interaction effects of democracy and political risk}

We continue by estimating the Equation (1) in its full form, including interaction terms. We proceed through the model selection algorithm for each of the estimations again and report the results in Table 4. Again, columns (1) and (2) report the results from pooled OLS, whereas columns (3), (4), (5) and (6) are the results from system GMM with full and collapsed instrument sets. Odd columns use polity as their democracy measure, whereas even columns use icrg.

\section{Table 4 here}

What can be seen is that the coefficients differ slightly between estimation methods and particularly the significance of the democracy and its interactions varies between democracy measures. While icrg-democracy provides consistently highly significant estimates, almost none of the coefficients 
involving polity is significant. This leads to conclude that our results are dependent on the democracy measure. Also, when interaction terms are taken into account, the polrisk-variable is found to be positive and statistically significant in all of the estimations. This supports the view that decreases in a country's political risk level increase local stock market returns. The results for democracy are also positive but significant for only half of the cases. In addition, Table 4 presents evidence that for icrg the coefficient of $\mathrm{dem}^{2}$ is statistically significant and negative, which indicates that when the democracy level reaches a certain threshold, its effect on returns becomes negative. Results for polity, however, cast some doubt on the results because the coefficients in them are not statistically significant, although they have identical signs with icrg. Based on the correlations (Table 2), the differences in results are mostly owning to Law and Order, Socioeconomic conditions, Investment profile, Military in politics and Internal conflicts (five largest differences in political risk component correlations with democracy measures). In addition, it may be noted from the pooled OLS estimations that the coefficient of determination increases 2-3 percentage points; thus, the total contribution of interaction terms is rather small.

An interesting and somewhat surprising result is that the coefficient of dem * polrisk is negative, although neither of the coefficients is negative independently. This would indicate that the higher the democracy level and lower the political risk, the smaller the returns which is by contrast to the expectations from the previous results. We relate this result to the quadratic relationship between political risk and democracy level which was demonstrated in Figures 1 and 2 with the following: polrisk $=\beta_{0}+\beta_{1} * d e m+\beta_{2} * d e m^{2}$. In this relationship, $\beta_{1}$ is negative and $\beta_{2}$ is positive, which indicates that political riskiness increases until a certain threshold democracy level and then begins to decrease after that. Thus, when the squared term of democracy, dem $^{2}$, is included in the regression, dem has a negative effect on political risk, which causes their interaction to be negative. Conversely, $\mathrm{dem}^{2}$ has a positive effect on polrisk. Table 4 shows further that separately estimated $d e m^{2}$ is negative and polrisk positive but their interaction term $\operatorname{dem}^{2} *$ 
polrisk is positive. Overall, these results suggest that, with this model specification, the democracy level, when measured with icrg, has effects on returns, both independently and interacting with political risk.

The weakening of the power of Hansen's test through the large number of instruments can be observed from the Hansen's test results in Table 4. When the instrument ratio is small (columns (3)-(4)), Hansen's test almost never rejects the validity of the instruments; thus, it might be more appropriate to study the results with a collapsed instrument set (columns (5)-(6)). In these results, Hansen's test does not reject any of our estimations with conventional significance levels but the $\mathrm{AR}(2)$ test is rejected with $10 \%$ level for polity. Because our pooled OLS estimations are not subject to either of these tests and continue to provide similar results to system GMM, we consider our results to be rather reliable. However, we continue to study the robustness of the results in Appendix 2.

\subsubsection{Interaction effects of democracy and political risk components}

Next, we study the effects of democracy on stock market performance more carefully and decompose the political risk component into its subcomponents and use these in Equation (1) separately as political risks. We aim to study whether these subcomponents exhibit similar behavior as the political risk component and report the results in Table 5. For each estimation method, we utilize the models found in the previous subsection; however, to converse space, we present the results only for the icrg index estimated with system GMM with collapsed instrument set and do not report results for the control variables. Full estimation results are available from the authors upon request.

Table 5 here 
Table 5 shows that all other political risk subcomponents except Ethnic tensions and Bureaucracy quality have positive signs and most of them are statistically significant. Of the components, Conflicts and tensions and Quality of instutions vectors, Government stability, Investment profile, Military in politics, Religious tensions and Law and order behave similarly as the political risk component with significant interaction terms with democracy and its squared term. None of these estimations can be rejected with $10 \%$ level based on the AR(2) test and Hansen's J test. It should, however, be noted that as was already mentioned in section 2.3, Military in politics and Religious tensions have positive correlations with the democracy that might affect the results for these subcomponents.

\section{Conclusions}

We study 49 emerging financial markets to discover whether their performance is related to their country's democracy level and, in particular, to its interaction with political risk. We use two measures for democracy and two panel data methods, pooled OLS and system GMM, to capture the direct and interaction effects of democracy and political risk on the global market adjusted 12month average returns.

We find evidence that the level of democracy of a country affects stock market returns interacting with political risk, particularly during the 2000-2012 period. We also provide (partly counter-intuitive) evidence that lower political risks are associated with higher returns which lends support to findings of Perotti and van Oijen (2001), Diamonte et al. (1996) and Erb et al. (1996a). Moreover, we find several other variables to affect local returns. In part, our findings also provide evidence about the segmentation of the emerging stock market from the world market. Nonetheless, a word of caution is in order. Our results do not pass all robustness tests and they are found to be democracy measure and time-period dependent. Thus the estimations highlight the importance of 
using several different democracy measures for estimations that include democracy because the results might differ among them.

Because the data on emerging market returns remains limited, more accurate results can only be obtained in the future as both the number of markets increases and the observation periods are elongated. Further analysis on the topic of democracy, political risk and stock market performance calls for a theoretical model. However, this study may operate as a pioneering empirical work on this topic and the basic idea can be extended to other sectors in finance, such as the bond markets and FDI flows. These ideas, however, are left for future studies.

\section{Acknowledgements}

The authors would like to thank the participants of the Midwest Finance Association Annual meeting 2013 in Chicago and the 2013 annual meeting of Finnish Economic Association in Mariehamn for their helpful comments. Part of the research was written while corresponding author was working as a visiting scholar at the Chazen Institute at Columbia Business School. The financial support from the Alfred Kordelin Foundation, OP Bank Research Foundation and the Yrjö Jahnsson Foundation are gratefully acknowledged. The study is part of JyIMFa research group activities. 


\section{References}

Acemoglu, D., Johnson, S., Robinson, J.A. and Yared, P., 2008. Income and Democracy, American Economic Review 98, 808-842.

Arellano, M. and Bond, S., 1991. Some tests of specification for panel data: Monte Carlo evidence and an application to employment equations, The Review of Economic Studies 58, 277-297.

Arellano, M. and Bover, O., 1995. Another look at the instrumental variable estimation of errorcomponents models, Journal of Econometrics 68, 29-51.

Asiedu, E. and Lien, D., 2011. Democracy, foreign direct investment and natural resources, Journal of International Economics 84, 99-111.

Barro, R., 1999. Determinants of democracy, The Journal of Political Economy 107, 158-183.

Bekaert, G. , 1995. Market integration and investment barriers in emerging equity markets, The World Bank Economic Review 9, 75-107.

Bekaert, G., Ehrmann, M., Fratzscher, M. and Mehl, A., 2014. Global crises and equity market contagion, Journal of Finance, Forthcoming.

Bekaert, G., Harvey, C.R. and Lundblad, C., 2011. Financial openness and productivity, World Development 39, 1-19. 
Bekaert,G., Harvey, C.R., Lundblad, C.T. and Siegel, S., 2011. What segments equity markets?, Review of Financial Studies 24, 3847-3890.

Bialkowski, J., Gottschalk, K. and Wisniewski, T.P., 2008. Stock market volatility around national elections, Journal of Banking and Finance 32, 1941-1953.

Bilson, C.M., Brailsford, T.J. and Hooper, V.C., 2002. The explanatory power of political risk in emerging markets, International Review of Financial Analysis 11, 1-27.

Blundell, R. and Bond. S., 1998. Initial conditions and moment restrictions in dynamic panel data models, Journal of Econometrics 87, 115-144.

Bun, M.J.K. and Windmeijer, F., 2010. The weak instrument problem of the system GMM estimator in dynamic panel data models, The Econometrics Journal 13, 95-126.

Casper, G. and Tufis, C., 2003. Correlation versus interchangeability: the limited robustness of empirical findings on democracy using highly correlated data sets, Political Analysis 11, 196-203.

Chen, N., Roll, R. and Ross, S.A., 1986. Economic forces and the stock market, The Journal of Business 59, 383-403.

Diamonte, R.L., Liew, J.M. and Stevens, R.L., 1996. Political risk in emerging and developed markets, Financial Analyst Journal 52, 71-76. 
Docouliagos, H. and Ulubasoğlu,M.,A., 2008. Democracy and Economic Growth: A MetaAnalysis, American Journal of Political Science 52, 61-83.

Erb, C.B., Harvey, C. R. and Viskanta, T.E., 1996a. Political risk, economic risk, and financial risk, Financial Analysts Journal 52, 29-46

Erb, C.B., Harvey, C. R. and Viskanta, T.E., 1996b. Expected returns and volatility in 135 countries. Journal of Portfolio Management 21, 32-48.

Flannery, M.J. and Protopapadakis, A.A., 2002. Macroeconomic factors do influence aggregate stock returns, The Review of Financial Studies 15, 751-782.

Foerster, S. and Schmitz, J., 1997. The transmission of US election cycles to international stock returns, Journal of International Business Studies 28, 1-27.

Gleditsch, N.P. and Hegre, H., 1997. Democracy and peace: Three levels of analysis, Journal of Conflict Resolution 41, 283-310.

Hansen, L., 1982. Large sample properties of generalized method of moments estimators, Econometrica 50, 1029-1054.

Hauk, W. and Wacziarg, R., 2009. A Monte Carlo study of growth regressions, Journal of Economic Growth 14, 103-147. 
Hayakawa, K., 2007. Small sample bias properties of the system GMM estimator in dynamic panel data models, Economic Letters 95, 32-38.

Hegre, H., Ellingsen, T., Gates, S. and Gleditsch, N.P., 2001. Toward a democratic civil peace? Democracy, political change, and civil war, 1816-1992. American Political Science Review 91, 3348.

Hendry, D.F. and Krolzig, H.M., 2005. The properties of automatic GETS modeling, The Economic Journal 115, C32-C61.

Lensink, R., Hermes N. and Murinde V., 2000. Capital flight and political risk, Journal of International Money and Finance 19, 73-92.

Mishkin, F. and White, E., 2002. US stock market crashes and their aftermath: implications for monetary policy. NBER Working Paper, vol. 8992.

Mobarak, A.,M., 2005. Democracy, volatility, and economic development. The Review of Economics and Statistics 87, 348-361.

Munck, G.L. and Verkuilen, J., 2002. Conceptualizing and measuring democracy: Evaluating alternative indices, Comparative Political Studies 35, 5-34.

Panzalis, C., Stangeland, D.A. and Turtle, H.J., 2000. Political elections and the resolution of uncertainty: The international evidence, Journal of Banking and Finance 24, 1575-1604. 
Perotti, E.C. and van Oijen, P., 2001. Privatization, political risk and stock market development in emerging markets, Journal of International Money and Finance 20, 43-69.

Persson, T. and Tabellini, G., 2007 The growth effect of democracy: Is it heterogeneous and how it can be estimated. NBER Working Paper, No.13150.

Rapach, D.E., Wohar, M.E. and Rangvid, J., 2005. Macro variables and international stock market predictability, International Journal of Forecasting 21, 137-166.

Reynal-Querol, M., 2002a. Ethnicity, political systems, and civil wars. Journal of Conflict Resolution 46, 29-54.

Reynal-Querol, M., 2002b. Political systems, stability and civil wars. Defense and Peace Economics $13,465-483$.

Rock, M., 2009. Corruption and democracy. Journal of Development Studies 45, 55-75.

Rodrik, D. and Wacziarg R., 2005. Do democratic transition produce bad economic outcomes?, American Economic Review 95, 50-55.

Roodman, D., 2006. How to do xtabond2: An introduction to "Difference" and "System" GMM in Stata, Center for Global Development, Working paper number 103.

Roodman, D., 2009. A note on the theme of too many instruments, Oxford Bulletin of Economics and Statistics 71, 135-158. 
Tavares, J and Wacziarg, R. 2001. How democracy affect growth. European Economic Review 45, 1341-1378.

Windmeijer, F., 2005. A finite sample correction for the variance of linear efficient two-step GMM estimators, Journal of Econometrics 126, 25-51. 


\section{Figures:}

Figure 1. Democracy and political risk

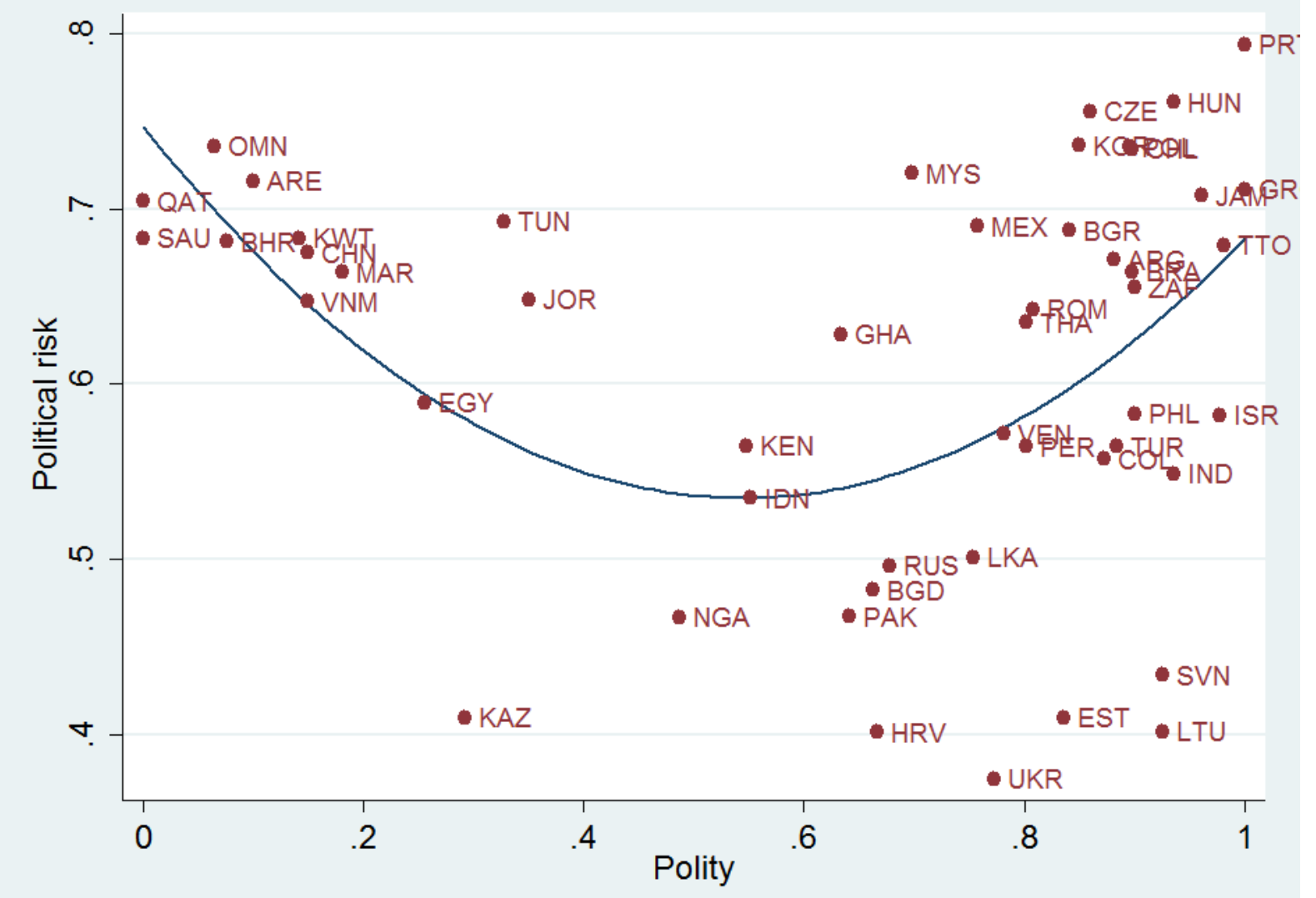

The data on democracy measured with polity and political risk measured with ICRG averaged over a maximum period of 1988 to 2010 with several starting years (see Table 1 for the starting year for each market). Both measures are normalized to an interval from zero to one, with a higher number indicating more democratic country and lower political risk. In total, there are 49 countries represented. A squared curve is fitted to the data points. The OLS regression of democracy on political risk with both the democracy and its squared value as independent factors yields the following: polrisk $=0.75-0.77 * \mathrm{dem}+0.71 * \mathrm{dem}^{2}$, with p-values of 0.000 and 0.001 , respectively, and $R^{2}=0.23$. 
Figure 2. Democracy and political risk.

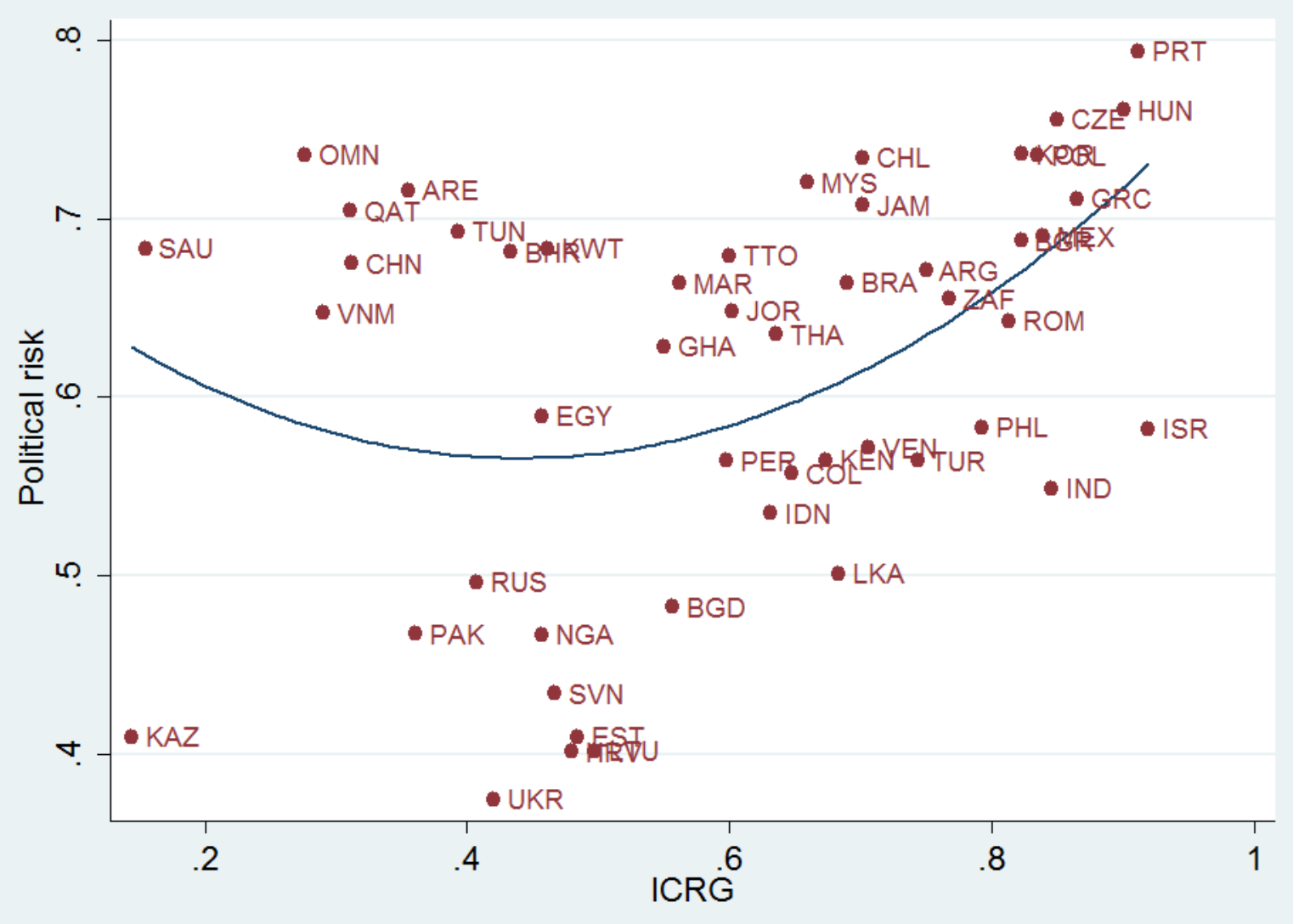

The data on democracy measured with icrg and political risk measured with ICRG averaged over a maximum period of 1988 to 2010 with several starting years (see Table 1 for the starting year for each market). Both of the measures are normalized to an interval from zero to one, where a higher number indicates a more democratic country and lower political risks. In total, there are 49 countries represented. A squared curve is fitted to the data points. The OLS regression of democracy on political risk with both the democracy and its squared value as independent factors yields the following: polrisk $=0.70-0.63 * d e m+0.72 * \mathrm{dem}^{2}$, with p-values of 0.110 and 0.038 , respectively, and $R^{2}=0.19$. 
Tables:

Table 1: Summary statistics

\begin{tabular}{|c|c|c|c|c|c|c|}
\hline Country & Code & First observation & Local returns [US \$] & Polity & ICRG & Political risks \\
\hline Greece & GRC & 1988 & 14.27 & 1.00 & 0.87 & 0.71 \\
\hline Portugal & PRT & 1988 & 7.12 & 1.00 & 0.91 & 0.79 \\
\hline Trinidad and Tobago & TTO & 2009 & 9.10 & 0.98 & 0.60 & 0.68 \\
\hline Israel & ISR & 1993 & 9.58 & 0.98 & 0.92 & 0.58 \\
\hline Jamaica & JAM & 2009 & 3.07 & 0.96 & 0.70 & 0.71 \\
\hline Hungary & HUN & 1995 & 19.32 & 0.94 & 0.90 & 0.76 \\
\hline India & IND & 1993 & 17.11 & 0.94 & 0.85 & 0.55 \\
\hline Lithuania & LTU & 2009 & 28.71 & 0.93 & 0.50 & 0.40 \\
\hline Slovenia & SVN & 2003 & 16.41 & 0.93 & 0.47 & 0.43 \\
\hline Philippines & PHL & 1988 & 17.71 & 0.90 & 0.79 & 0.58 \\
\hline South Africa & ZAF & 1993 & 15.82 & 0.90 & 0.77 & 0.65 \\
\hline Brazil & BRA & 1988 & 30.72 & 0.90 & 0.69 & 0.66 \\
\hline Chile & CHL & 1988 & 21.84 & 0.90 & 0.70 & 0.73 \\
\hline Poland & POL & 1993 & 44.57 & 0.89 & 0.83 & 0.74 \\
\hline Turkey & TUR & 1988 & 45.42 & 0.88 & 0.74 & 0.56 \\
\hline Argentina & ARG & 1988 & 34.00 & 0.88 & 0.75 & 0.67 \\
\hline Colombia & $\mathrm{COL}$ & 1993 & 24.03 & 0.87 & 0.65 & 0.56 \\
\hline Czech Republic & CZE & 1995 & 15.88 & 0.86 & 0.85 & 0.76 \\
\hline South Korea & KOR & 1988 & 17.92 & 0.85 & 0.82 & 0.74 \\
\hline Bulgaria & BGR & 2006 & 7.10 & 0.84 & 0.82 & 0.69 \\
\hline Estonia & EST & 2003 & 21.43 & 0.84 & 0.48 & 0.41 \\
\hline Romania & ROM & 2006 & 9.72 & 0.81 & 0.81 & 0.64 \\
\hline Peru & PER & 1993 & 22.13 & 0.80 & 0.60 & 0.56 \\
\hline Thailand & THA & 1988 & 20.12 & 0.80 & 0.64 & 0.64 \\
\hline Venezuela & VEN & 2011 & -23.71 & 0.78 & 0.71 & 0.57 \\
\hline Ukraine & UKR & 2007 & -15.32 & 0.77 & 0.42 & 0.37 \\
\hline Mexico & MEX & 1988 & 27.29 & 0.76 & 0.84 & 0.69 \\
\hline Sri Lanka & LKA & 1993 & 16.88 & 0.75 & 0.68 & 0.50 \\
\hline Malaysia & MYS & 1988 & 16.23 & 0.70 & 0.66 & 0.72 \\
\hline Russia & RUS & 1995 & 38.24 & 0.68 & 0.41 & 0.50 \\
\hline Croatia & HRV & 2003 & 15.64 & 0.67 & 0.48 & 0.40 \\
\hline Bangladesh & BGD & 2010 & -1.00 & 0.66 & 0.56 & 0.48 \\
\hline Pakistan & PAK & 1993 & 19.71 & 0.64 & 0.36 & 0.47 \\
\hline Ghana & GHA & 2009 & 17.84 & 0.63 & 0.55 & 0.63 \\
\hline Indonesia & IDN & 1988 & 28.81 & 0.55 & 0.63 & 0.53 \\
\hline Kenya & KEN & 2003 & 38.38 & 0.55 & 0.67 & 0.56 \\
\hline Nigeria & NGA & 2003 & 25.51 & 0.49 & 0.46 & 0.47 \\
\hline Jordan & JOR & 1988 & 5.98 & 0.35 & 0.60 & 0.65 \\
\hline Tunisia & TUN & 2005 & 10.45 & 0.33 & 0.39 & 0.69 \\
\hline Kazakhstan & $\mathrm{KAZ}$ & 2006 & 15.59 & 0.29 & 0.14 & 0.41 \\
\hline Egypt & EGY & 1995 & 28.80 & 0.26 & 0.46 & 0.59 \\
\hline Morocco & MAR & 1995 & 12.24 & 0.18 & 0.56 & 0.66 \\
\hline
\end{tabular}




\begin{tabular}{|lllllll|}
\hline China & CHN & 1993 & 7.80 & 0.15 & 0.31 & 0.67 \\
Vietnam & VNM & 2007 & -1.80 & 0.15 & 0.29 & 0.65 \\
Kuwait & KWT & 2006 & 2.44 & 0.14 & 0.46 & 0.68 \\
United Arab Emirates & ARE & 2006 & 6.72 & 0.10 & 0.35 & 0.72 \\
Bahrain & BHR & 2006 & -12.69 & 0.08 & 0.43 & 0.68 \\
Oman & OMN & 2006 & 5.63 & 0.06 & 0.28 & 0.74 \\
Qatar & QAT & 2006 & 7.82 & 0.00 & 0.31 & 0.70 \\
Saudi Arabia & SAU & 2006 & 4.14 & 0.00 & 0.15 & 0.68 \\
\hline
\end{tabular}

Notes: First observation is the starting year of the data for each of the markets. Local returns refer to annual mean of local returns of MSCI country indices denominated in the U.S. dollars. The democracy variables polity and icrg are from Polity IV and International Country Risk Guide (ICRG), respectively. The data are normalized to lie between zero and one, where a higher number indicates a more democratic country. Political risk is the composite index of ICRG political risk index normalized to an interval from zero to one consisting of 11 subcomponents: Bureaucracy quality, Corruption, Ethnic tensions, External conflicts, Internal conflicts, Government stability, Investment proficiency, Law and Order, Military in politics, Religious tensions and Socioeconomic conditions. The higher number indicates a smaller political risk. The table is sorted according to polity.

Table 2: Correlations between democracy and political risk measures

\begin{tabular}{|lll|}
\hline ICRG & Polity & ICRG \\
Political risk & 0.7408 & \\
Bureaucracy quality & 0.0925 & 0.2394 \\
Corruption & 0.3125 & 0.4076 \\
Ethnic tensions & 0.2281 & 0.2745 \\
External conflicts & -0.1100 & -0.0238 \\
Internal conflicts & 0.1501 & 0.1391 \\
Government stability & 0.0465 & 0.1651 \\
Investment profile & -0.1679 & -0.1466 \\
Law and Order & 0.1332 & 0.2815 \\
Military in politics & -0.1006 & 0.0787 \\
Religious tensions & 0.2361 & 0.3582 \\
Socioeconomic conditions & 0.2863 & 0.2658 \\
\hline
\end{tabular}


Table 3: The direct effects of democracy and political risk to stock market behavior

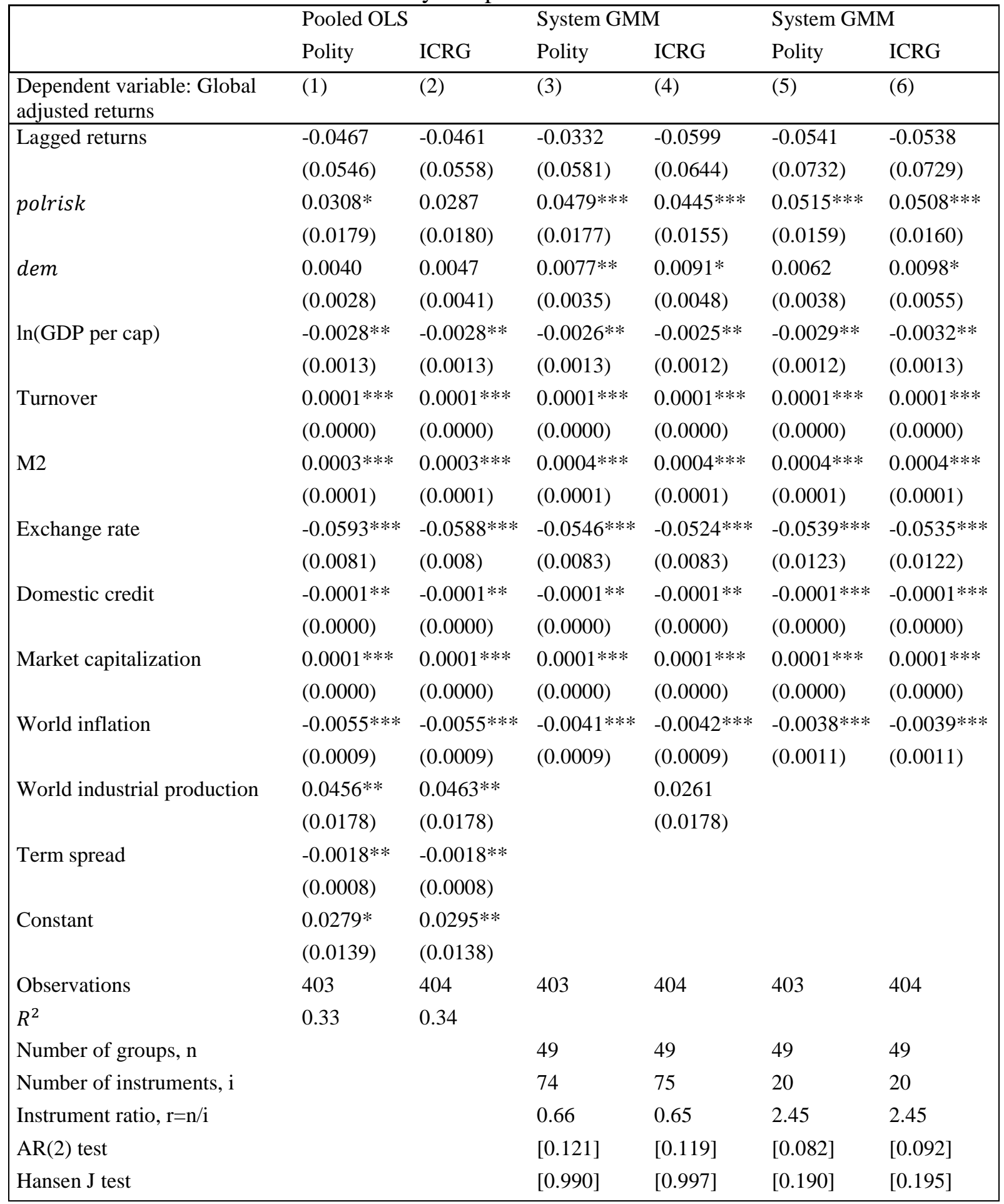

Notes: Estimation results of Equation (1) without interaction terms with a 12-month average of world market adjusted local returns as dependent variable. The estimations are performed with the following three methods: pooled OLS (columns (1) and (2)), system GMM by Blundell and Bond (1998) (columns (3) and (4)) and system GMM with collapsed instrument set (columns (5) and (6)). The base sample is an unbalanced yearly panel data from 2000 to 2012 for 49 emerging stock markets. For more detailed data, definitions and sources, see Appendix 1, Table 1. ***, ** and * denote statistical significance at a $1 \%, 5 \%$ and $10 \%$ level, respectively. In the Hansen test, the null hypothesis is that the instruments are not correlated with residuals, whereas in the AR(2) test, the 
null hypothesis is that the errors in the first difference regression exhibit no second order serial correlation. Heteroskedasticity robust standard errors are in parenthesis.

Table 4: Interaction effects of democracy and political risk to world market adjusted local returns

\begin{tabular}{|c|c|c|c|c|c|c|}
\hline \multirow{2}{*}{\begin{tabular}{|l|} 
\\
Dependent variable: \\
World market adjusted return
\end{tabular}} & \multicolumn{2}{|l|}{ Pooled OLS } & \multicolumn{2}{|c|}{ System GMM } & \multicolumn{2}{|c|}{ System GMM } \\
\hline & Polity & ICRG & Polity & ICRG & Polity & ICRG \\
\hline & (1) & (2) & (3) & (4) & (5) & (6) \\
\hline \multirow[t]{2}{*}{ Lagged returns } & -0.0447 & -0.0542 & -0.0416 & -0.0392 & -0.0542 & -0.0549 \\
\hline & $(0.0546)$ & $(0.0553)$ & $(0.0570)$ & $(0.0774)$ & $(0.0744)$ & $(0.0763)$ \\
\hline \multirow[t]{2}{*}{ polrisk } & $0.0831 * * *$ & $0.1698 * * *$ & $0.0714 * * *$ & $0.2286^{* * *}$ & $0.0642 * * *$ & $0.2003 * * *$ \\
\hline & $(0.0223)$ & $(0.0445)$ & $(0.0240)$ & $(0.0550)$ & $(0.0230)$ & $(0.0393)$ \\
\hline \multirow[t]{2}{*}{ dem } & 0.1279 & $0.3728 * * *$ & 0.0465 & $0.4855^{* * *}$ & 0.1021 & $0.4077 * * *$ \\
\hline & $(0.0789)$ & $(0.1209)$ & $(0.0945)$ & $(0.1442)$ & $(0.1115)$ & $(0.1408)$ \\
\hline \multirow[t]{2}{*}{$\mathrm{dem}^{2}$} & -0.0925 & $-0.2929 * *$ & -0.0221 & $-0.3765 * * *$ & -0.0996 & $-0.3180 * *$ \\
\hline & $(0.0835)$ & $(0.1100)$ & $(0.1014)$ & $(0.1311)$ & $(0.1142)$ & $(0.1352)$ \\
\hline \multirow[t]{2}{*}{ dem * polrisk } & $-0.2094 *$ & $-0.5178 * * *$ & -0.1143 & $-0.6782 * * *$ & -0.1795 & $-0.5855^{* * *}$ \\
\hline & $(0.1201)$ & $(0.1741)$ & $(0.1405)$ & $(0.2094)$ & $(0.1670)$ & $(0.2031)$ \\
\hline \multirow[t]{2}{*}{ dem $^{2} *$ polrisk } & 0.1623 & $0.4110^{* *}$ & 0.0814 & $0.5340 * * *$ & 0.1806 & $0.4675^{* *}$ \\
\hline & $(0.1233)$ & $(0.1567)$ & $(0.1457)$ & $(0.1867)$ & $(0.1660)$ & $(0.1929)$ \\
\hline \multirow[t]{2}{*}{$\ln (G D P$ per capita $)$} & $-0.0035 * *$ & $-0.0032 * *$ & $-0.0036 * *$ & $-0.0034 * *$ & $-0.0035 * *$ & $-0.0035^{* *}$ \\
\hline & $(0.0015)$ & $(0.0014)$ & $(0.0016)$ & $(0.0016)$ & $(0.0015)$ & $(0.0015)$ \\
\hline \multirow[t]{2}{*}{ Turnover } & $0.0001 * * *$ & $0.0001 * * *$ & $0.0001 * *$ & $0.0001 * * *$ & $0.0001 * * *$ & $0.0001 * * *$ \\
\hline & $(0.0000)$ & $(0.0000)$ & $(0.0000)$ & $(0.0000)$ & $(0.0000)$ & $(0.0000)$ \\
\hline \multirow[t]{2}{*}{ M2 } & $0.0003 * * *$ & $0.0003 * * *$ & $0.0005 * * *$ & $0.0003 * * *$ & $0.0004 * * *$ & $0.0004 * * *$ \\
\hline & $(0.0001)$ & $(0.0001)$ & $(0.0001)$ & $(0.0001)$ & $(0.0001)$ & $(0.0001)$ \\
\hline \multirow[t]{2}{*}{ Exchange rate } & $-0.0587 * * *$ & $-0.0572 * * *$ & $-0.0553 * * *$ & $-0.0465 * * *$ & $-0.0535 * * *$ & $-0.0517 * * *$ \\
\hline & $(0.0081)$ & $(0.0076)$ & $(0.0095)$ & $(0.0093)$ & $(0.0118)$ & $(0.0121)$ \\
\hline \multirow[t]{2}{*}{ Domestic credit } & $-0.0001 * *$ & $-0.0001 * * *$ & $-0.0001 * *$ & $-0.0001 * * *$ & $-0.0001 * * *$ & $-0.0002 * * *$ \\
\hline & $(0.0000)$ & $(0.0000)$ & $(0.0000)$ & $(0.0000)$ & $(0.0000)$ & $(0.0000)$ \\
\hline \multirow[t]{2}{*}{ Market capitalization } & $0.0001 * * *$ & $0.0001 * * *$ & $0.0001 * * *$ & $0.0001 * * *$ & $0.0001 * * *$ & $0.0001 * * *$ \\
\hline & $(0.0000)$ & $(0.0000)$ & $(0.0000)$ & $(0.0000)$ & $(0.0000)$ & $(0.0000)$ \\
\hline \multirow[t]{2}{*}{ World inflation } & $-0.0055 * * *$ & $-0.0054 * * *$ & $-0.0044 * * *$ & $-0.0047 * * *$ & $-0.0037 * * *$ & $-0.0038 * * *$ \\
\hline & $(0.0009)$ & $(0.0009)$ & $(0.0011)$ & $(0.0011)$ & $(0.0012)$ & $(0.0012)$ \\
\hline \multirow[t]{2}{*}{ World industrial production } & $0.0463 * *$ & $0.0479 * *$ & $0.0309 *$ & $0.0388 * *$ & & \\
\hline & $(0.0180)$ & $(0.0181)$ & $(0.0177)$ & $(0.0189)$ & & \\
\hline \multirow[t]{2}{*}{ Term spread } & $-0.0018 * *$ & $-0.0018 * * *$ & & -0.0013 & & \\
\hline & $(0.0007)$ & $(0.0007)$ & & $(0.0008)$ & & \\
\hline \multirow[t]{2}{*}{ Constant } & & $-0.0680 * *$ & & $-0.1131 * * *$ & & $-0.0986^{* * *}$ \\
\hline & & $(0.0263)$ & & $(0.0317)$ & & $(0.0253)$ \\
\hline Observations & 403 & 404 & 403 & 404 & 403 & 404 \\
\hline$R^{2}$ & 0.36 & 0.35 & & & & \\
\hline Number of groups, $n$ & & & 49 & 49 & 49 & 49 \\
\hline Number of instruments, $\mathrm{i}$ & & & 78 & 80 & 23 & 24 \\
\hline Instrument ratio, $\mathrm{r}=\mathrm{n} / \mathrm{i}$ & & & 0.63 & 0.61 & 2.13 & 2.04 \\
\hline
\end{tabular}




\begin{tabular}{|lllll|} 
AR(2) test & {$[0.114]$} & {$[0.187]$} & {$[0.082]$} & {$[0.103]$} \\
Hansen J test & {$[0.999]$} & {$[0.994]$} & {$[0.184]$} & {$[0.176]$} \\
\hline
\end{tabular}

Notes: Estimation results of Equation (1) with 12-month average of world-market-adjusted local returns as dependent variable. The estimations are performed with the following methods: pooled OLS (columns (1) and (2)), system GMM by Blundell and Bond (1998) (columns (3) and (4)) and system GMM with collapsed instrument set (columns (5) and (6)). The base sample is an unbalanced yearly panel data from 2000 to 2012 for 49 emerging stock markets. For more detailed data, definitions and sources, see Appendix 1, Table 1. ***,** and $*$ denote statistical significance at a $1 \%, 5 \%$ and $10 \%$ level, respectively. In the Hansen test, the null hypothesis is that the instruments are not correlated with residuals, whereas in the AR(2) test, the null hypothesis is that the errors in the first difference regression exhibit no second order serial correlation. Heteroskedasticity robust standard errors are in parenthesis. 
Table 5: Interaction effects of democracy and individual political risks to stock market behavior

\begin{tabular}{|c|c|c|c|c|c|c|c|c|c|c|c|c|c|}
\hline \multicolumn{14}{|c|}{ Dependent variable: World market adjusted local returns } \\
\hline $\begin{array}{l}\text { Political } \\
\text { variable }\end{array}$ & $\begin{array}{l}\text { Conflicts } \\
\text { and } \\
\text { tensions }\end{array}$ & $\begin{array}{l}\text { Quality of } \\
\text { institutions }\end{array}$ & $\begin{array}{l}\text { Government } \\
\text { stability }\end{array}$ & $\begin{array}{l}\text { Socioecon } \\
\text { omic } \\
\text { conditions }\end{array}$ & $\begin{array}{l}\text { Investment } \\
\text { profile }\end{array}$ & $\begin{array}{l}\text { Internal } \\
\text { conflict }\end{array}$ & $\begin{array}{l}\text { External } \\
\text { conflict }\end{array}$ & Corruption & $\begin{array}{l}\text { Military in } \\
\text { politics }\end{array}$ & $\begin{array}{l}\text { Religious } \\
\text { tensions }\end{array}$ & $\begin{array}{l}\text { Law and } \\
\text { order }\end{array}$ & $\begin{array}{l}\text { Ethnic } \\
\text { tensions }\end{array}$ & $\begin{array}{l}\text { Bureaucracy } \\
\text { quality }\end{array}$ \\
\hline \multirow[t]{2}{*}{ polrisk } & $0.1178 * * *$ & $0.2036^{* * *}$ & $0.1877 * * *$ & $0.1412 * * *$ & $0.0799 * *$ & $0.1072 * *$ & $0.0756^{*}$ & 0.0528 & $0.0401 * * *$ & $0.0803 * * *$ & $0.1505^{* * *}$ & -0.0009 & -0.0080 \\
\hline & $(0.0339)$ & $(0.0730)$ & $(0.0333)$ & $(0.0456)$ & $(0.0332)$ & $(0.0450)$ & $(0.0449)$ & $(0.0527)$ & $(0.0155)$ & $(0.0200)$ & $(0.0412)$ & $(0.0371)$ & $(0.0607)$ \\
\hline \multirow[t]{2}{*}{ dem } & $0.2740 * *$ & $0.3076^{* *}$ & $0.4352 * * *$ & $0.1937 *$ & $0.3304 * *$ & $0.2467 *$ & 0.2047 & 0.1407 & $0.1291 *$ & $0.1589 * * *$ & $0.2987 * * *$ & -0.0129 & -0.0368 \\
\hline & $(0.1142)$ & $(0.1414)$ & $(0.1167)$ & $(0.1009)$ & $(0.1347)$ & $(0.1443)$ & $(0.2439)$ & $(0.1000)$ & $(0.0684)$ & $(0.0563)$ & $(0.1101)$ & $(0.0927)$ & $(0.1198)$ \\
\hline \multirow[t]{2}{*}{$\operatorname{dem}^{2}$} & $-0.2138^{* *}$ & $-0.2076^{*}$ & $-0.2842 * * *$ & -0.1122 & $-0.2930^{* *}$ & -0.1920 & -0.1662 & -0.1222 & $-0.1115^{*}$ & $-0.1176^{* *}$ & $-0.2063^{* *}$ & 0.0240 & 0.0485 \\
\hline & $(0.1079)$ & $(0.1151)$ & $(0.1096)$ & $(0.0792)$ & $(0.1253)$ & $(0.1363)$ & $(0.2152)$ & $(0.0818)$ & $(0.0640)$ & $(0.0526)$ & $(0.0969)$ & $(0.0771)$ & $(0.0870)$ \\
\hline \multirow{2}{*}{ dem $*$ polrisk } & $-0.3645^{* *}$ & $-0.5485^{* *}$ & $-0.5450 * * *$ & $-0.3213^{* *}$ & $-0.4054 * * *$ & -0.3165 & -0.2444 & -0.3153 & $-0.1861 * *$ & $-0.2605 * * *$ & $-0.4080 * *$ & 0.0492 & 0.0813 \\
\hline & $(0.1546)$ & $(0.2452)$ & $(0.1581)$ & $(0.1540)$ & $(0.1514)$ & $(0.1995)$ & $(0.2835)$ & (0.1979) & $(0.0891)$ & $(0.0820)$ & $(0.1717)$ & $(0.1646)$ & $(0.1902)$ \\
\hline \multirow[t]{2}{*}{ dem $^{2} *$ polrisk } & $0.2925 * *$ & $0.3790^{*}$ & $0.3714 * *$ & 0.1976 & $0.3684 * * *$ & 0.2565 & 0.2087 & $0.2933 *$ & $0.1681 * *$ & $0.2010 * * *$ & $0.2946^{*}$ & -0.0464 & -0.0819 \\
\hline & $(0.1435)$ & $(0.2006)$ & $(0.1512)$ & $(0.1244)$ & $(0.1419)$ & $(0.1841)$ & $(0.2498)$ & $(0.1637)$ & $(0.0856)$ & $(0.0768)$ & $(0.1517)$ & $(0.1349)$ & $(0.1355)$ \\
\hline $\begin{array}{l}\text { Number of } \\
\text { groups, } \mathrm{n}\end{array}$ & 404 & 404 & 404 & 404 & 404 & 404 & 404 & 404 & 404 & 404 & 404 & 404 & 404 \\
\hline $\begin{array}{l}\text { Number of } \\
\text { instruments, i }\end{array}$ & 49 & 49 & 49 & 49 & 49 & 49 & 49 & 49 & 49 & 49 & 49 & 49 & 49 \\
\hline $\begin{array}{l}\text { Instrument ratio, } \\
\mathrm{r}=\mathrm{n} / \mathrm{i}\end{array}$ & 24 & 24 & 24 & 24 & 24 & 24 & 24 & 24 & 24 & 24 & 24 & 24 & 24 \\
\hline $\begin{array}{l}\text { Number of } \\
\text { observations }\end{array}$ & 2.04 & 2.04 & 2.04 & 2.04 & 2.04 & 2.04 & 2.04 & 2.04 & 2.04 & 2.04 & 2.04 & 2.04 & 2.04 \\
\hline $\mathrm{AR}(2)$ test & {$[0.110]$} & {$[0.102]$} & {$[0.151]$} & {$[0.091]$} & {$[0.102]$} & [0.112] & [0.109] & [0.129] & [0.131] & {$[0.121]$} & {$[0.125]$} & [0.104] & [0.117] \\
\hline Hansen $\mathbf{J}$ test & {$[0.140]$} & {$[0.156]$} & {$[0.157]$} & [0.133] & {$[0.141]$} & {$[0.126]$} & [0.134] & [0.120] & [0.106] & [0.116] & [0.180] & {$[0.126]$} & [0.120] \\
\hline
\end{tabular}

Notes: Heteroskedasticity robust standard errors in parenthesis. $* * * * *$ and $*$ denote statistical significance at 1,5 and $10 \%$ level, respectively. 


\section{Appendix 1}

Table 1: Description of the variables

\begin{tabular}{|c|c|}
\hline Variable & scription \\
\hline \multicolumn{2}{|l|}{ Dependent variable } \\
\hline $\begin{array}{l}\text { Annual global } \\
\text { market adjusted } \\
\text { returns }\end{array}$ & $\begin{array}{l}\text { 12-month mean of global market adjusted local returns. Local market performance is measured with the } \\
\text { MSCI Standard Total Return indices that combine the prices with reinvested dividends. Global market is } \\
\text { measured with the MSCI World index. All indices are denominated in the U.S dollars. Source: MSCI Global } \\
\text { Equity Indices. }\end{array}$ \\
\hline \multicolumn{2}{|c|}{ Measures of democracy } \\
\hline $\begin{array}{l}\text { Institutionalized } \\
\text { democracy vs. } \\
\text { autocracy }\end{array}$ & $\begin{array}{l}\text { The difference between Polity IV's Democracy and Autocracy indices. Both of the indices measure the } \\
\text { competitiveness of political participation, the regulation of participation, the openness, the competitiveness } \\
\text { of executive recruitment and constraints on the governmental chief executive; these range from } 0 \text { to } 10 \text {. Thus } \\
\text { the Polity index varies between }-10 \text { and 10, where a higher number indicates higher democracy. Source: } \\
\text { Polity IV. }\end{array}$ \\
\hline $\begin{array}{l}\text { Democratic } \\
\text { accountability } \\
\text { Measures of politi }\end{array}$ & $\begin{array}{l}\text { Measures the level of democracy by studying the type of governance on the basis of the freedom and } \\
\text { fairness of the elections, the presence of political parties and opposition, the existence of legal protection of } \\
\text { personal liberties and the accountability of the government to its electorate. The index ranges from one to } \\
\text { six, where a higher number denotes higher democracy. Source: International Country Risk Guide. } \\
\text { al risk }\end{array}$ \\
\hline $\begin{array}{l}\text { Government } \\
\text { stability }\end{array}$ & $\begin{array}{l}\text { Measures both the government's ability to undertake its declared programs and its ability to stay in office. } \\
\text { The measure consists of the following three subcomponents, each scored } 0-4 \text { points: Government unity, } \\
\text { Legislative strength and Popular support. Thus the data ranges from } 0-12 \text { points, where a higher number } \\
\text { denotes lower risk. Source: International Country Risk Guide. }\end{array}$ \\
\hline External conflicts & $\begin{array}{l}\text { Measures the risk of foreign actions on governance. The actions could range from diplomatic pressures, } \\
\text { trade restrictions, sanctions, etc. to violent external pressure. The variable is measured with three } \\
\text { subcomponents ranging from 0-4: War, Cross-border conflict and Foreign pressures. The maximum of } 12 \\
\text { points denotes very low risk. Source: International Country Risk Guide. }\end{array}$ \\
\hline Internal co & $\begin{array}{l}\text { Measure political violence and its actual or potential impacts to governance with the following three } \\
\text { subcomponents, each scored 0-4 points: Civil War/Coup threat, Terrorism/Political violence, Civil disorder. } \\
\text { Maximum points } 12 \text { denote very low risk. Source: International Country Risk Guide. }\end{array}$ \\
\hline Ethnic tensions & $\begin{array}{l}\text { An assessment of the degree of tension within a country attributable to racial, nationality or language } \\
\text { divisions. Higher ratings are given to countries in which tensions are minimal whereas lower ratings are } \\
\text { given to countries in which racial and nationality tensions are high because opposing groups are intolerant } \\
\text { and unwilling to compromise. Maximum points are } 6 \text {. Source: International Country Risk Guide. }\end{array}$ \\
\hline $\begin{array}{l}\text { Military in } \\
\text { politics }\end{array}$ & $\begin{array}{l}\text { Assesses in what measure the military is involved in politics on a 0-6 point scale. The higher the number, the } \\
\text { lower the military participation to the politics and the lower the risk. Source: International Country Risk } \\
\text { Guide. }\end{array}$ \\
\hline $\begin{array}{l}\text { Religious } \\
\text { tensions }\end{array}$ & $\begin{array}{l}\text { Measures with a scale of 0-6 points whether a single religious group is able to affect a country's politics. The } \\
\text { higher the number, the lower the single religion group's effect. Source: International Country Risk Guide. }\end{array}$ \\
\hline $\begin{array}{l}\text { Socioeconomic } \\
\text { conditions }\end{array}$ & $\begin{array}{l}\text { Measures socioeconomic pressures in society that might affect government actions or fuel social } \\
\text { dissatisfaction with three subcomponents scored 0-4: Unemployment, Consumer confidence and Poverty. } \\
\text { Maximum of } 12 \text { points denotes very low risk. Source: International Country Risk Guide. }\end{array}$ \\
\hline $\begin{array}{l}\text { Investment } \\
\text { profile }\end{array}$ & $\begin{array}{l}\text { Measures the factors of investment risks that are not covered by other political, economic and financial risk } \\
\text { components with the following three subcomponents scored 0-4: Contract viability/Expropriation, Profits } \\
\text { repatriation, Payment delays. Maximum } 12 \text { points denotes very low risk. Source: International Country Risk } \\
\text { Guide }\end{array}$ \\
\hline $\begin{array}{l}\text { Bureaucracy } \\
\text { quality }\end{array}$ & $\begin{array}{l}\text { Measures whether the bureaucracy has the strength and expertise to govern without drastic changes in policy } \\
\text { or interruptions in government services. In low-risk countries, the bureaucracy tends to be somewhat } \\
\text { autonomous from political pressure and to have an established mechanism for recruiting and training. } \\
\text { Maximum points: } 4 \text {. Source: International Country Risk Guide. }\end{array}$ \\
\hline Corruption & $\begin{array}{l}\text { Measures the corruption within the political system on a scale of } 0-6 \text {, where the higher points denote less } \\
\text { corruption. Source: International Country Risk Guide. }\end{array}$ \\
\hline Law and order & $\begin{array}{l}\text { Law and order are assessed separately, with each sub-component consisting of zero to three points. The Law } \\
\text { sub-component is an assessment of the strength and impartiality of the legal system, whereas the Order sub- } \\
\text { component is an assessment of popular observance of the law. Thus a country can enjoy a high rating (3) in } \\
\text { terms of its judicial system, but a low rating (1) if it suffers from a high crime rate or if the law is routinely } \\
\text { ignored without effective sanction. A higher number denotes lower risk. Source: International Country Risk } \\
\text { Guide. }\end{array}$ \\
\hline
\end{tabular}




\begin{tabular}{|c|c|}
\hline $\begin{array}{l}\text { institutions } \\
\text { Conflicts and } \\
\text { tensions } \\
\text { Banking sector } d e\end{array}$ & $\begin{array}{l}\text { The sum of the following International Country Risk Guide (ICRG) political risk sub-components: } \\
\text { corruption, law and order, and bureaucratic quality. Source: International Country Risk Guide. } \\
\text { The sum of the following ICRG political risk sub-components: External conflicts, internal conflicts, ethnic } \\
\text { tensions and religious tensions. Source: International Country Risk Guide. } \\
\text { elopment }\end{array}$ \\
\hline $\begin{array}{l}\text { Domestic credit } \\
\text { to private sector } \\
\text { (\% of GDP) } \\
\text { Measures of finar }\end{array}$ & $\begin{array}{l}\text { Domestic credit to private sector refers to financial resources provided to the private sector, such as through } \\
\text { loans, purchases of nonequity securities, and trade credits and other accounts receivable that establish a } \\
\text { claim for repayment. } \\
\text { ial development }\end{array}$ \\
\hline $\begin{array}{l}\text { Market } \\
\text { capitalization of } \\
\text { listed companies }\end{array}$ & $\begin{array}{l}\text { The share price times the number of shares outstanding of listed domestic companies. Measured as } \\
\text { percentage of GDP. Source: World Bank Development Indicators. }\end{array}$ \\
\hline Macroeconomic c & $\begin{array}{l}\text { ided during the period divided by the average market } \\
\text { Development Indicators. }\end{array}$ \\
\hline capita & duct divided by midyear population. Measured in U.S. dollars. Source: \\
\hline GDP & $\begin{array}{l}\text { Annual percentage growth rate of GDP at market prices based on constant local currency. Source: World } \\
\text { Bank Development Indicators. }\end{array}$ \\
\hline Inflation & $\begin{array}{l}\text { Inflation as measured by the annual } \mathrm{g} \\
\text { change in the economy as a whole. Sou }\end{array}$ \\
\hline Exch & Source: Dat \\
\hline M1 & wth. Source: World Bank Development Indicators. \\
\hline M2 & velopmen \\
\hline International risk & $\begin{array}{l}\text { Annual changes in the industrial production indices. For oil-producing countries, the industrial production is } \\
\text { calculated as the annual logarithmic changes in the production multiplied by the price of the oil. Source: } \\
\text { Datastream. } \\
\text { actors }\end{array}$ \\
\hline World inflation & entage. Source: Dat \\
\hline $\begin{array}{l}\text { industrial } \\
\text { ion } \\
\text { e }\end{array}$ & $\begin{array}{l}\text { 12-month mean of the logarithmic changes in the world industrial production (advanced countries). Source: } \\
\text { Datastream. } \\
\text { 12-month mean of the logarithmic changes in Brent oil price returns. Source: Datastream. }\end{array}$ \\
\hline Credit spread & $\begin{array}{l}\text { Corporate bond yield spread between U.S. Baa and Aaa rated bonds. Source: Federal Reserve Bank of St. } \\
\text { Louis. }\end{array}$ \\
\hline Term & ear bond yield minus 3-month U.S. Treasury bill rate. Source: Datastr \\
\hline
\end{tabular}




\section{Appendix 2}

\section{Robustness tests}

Our original estimation strategy already included robustness checking by utilizing two different estimation methods, two different measures for democracy and results with and without limiting the instrument amount, we will provide further robustness checks as evidence for our results.

For these robustness regressions, we use the icrg index as our measure for democracy and limit the number of instruments when required (i.e., when the instrumental ratio would be higher than one otherwise) to avoid biased results that might be caused by a high ratio between the number of countries and instruments. We use the models found in subsection 4.1.2. To conserve space, we do not report all of the results, instead we concentrate on the direct and interaction effects of political risk and democracy for market returns and summarize the estimations in Appendix 2, Tables 1, 2 and 3. In general, we aim to test the robustness of our results from several different angles by using Equation (1) as our base model.

(i) Analysis period and time fixed effects. It is possible that our results might be driven by the choice of our analysis period. Thus, we will examine the results for several starting periods: 1988, 1995 and 2005. In addition, as Roodman (2006) recommends, we introduce the time dummies to our original dataset to control for potential time-related shocks and to increase the probability that there is no correlation across individuals in idiosyncratic disturbances, which is the assumption behind the autocorrelation test. The instrument sets are collapsed in all cases except for the 2005-2012 period. The results for these estimations, and for our original time period with time fixed effects, can be found in Appendix 2, Table 1. As the estimations show, introducing time fixed effects does not change our original results much, but the significance of our results is affected by the time interval. Pooled OLS provides rather similar results across the different datasets but system GMM estimations show almost no significant results. However, the political risk 
variable is still positive in all and significant in half of the estimations. It should be noted that the Hansen test for period 2005-2010 is rejected at the $10 \%$ level; thus, these results should be interpreted with caution. The results remain similar when time fixed effects are included to all estimations.

\section{Appendix 2, Table 1 here}

(ii) Outliers. It is also possible that certain countries that are more vulnerable to political instabilities might affect our results. We investigate the sensitivity of our results for outliers by dropping several of the most (Croatia, Kazakhstan, Lithuania and Ukraine) and the least (Czech Republic, Hungary, Portugal and South Korea) politically risky countries from our dataset. In addition, because we are studying democracy, we also drop separately several of the most (Greece, Israel, Portugal and Trinidad and Tobago) and the least (Bahrain, Oman, Qatar and Saudi Arabia) democratic countries from our dataset. These results can be found in Appendix 2, Table 2. As the estimations show, our original results remain identical in terms of statistical significance, for the political risk component and the interaction terms in particular.

\section{Appendix 2, Table 2 here}

(iii) Development. Although we already take into account a country's development level in our base model, we continue to study whether the development level affects our results. However, dividing countries into low-, middle- and high-income countries would lead to subsamples that are too small and too low estimation reliability levels because the instrument ratio would be high. Instead, we include the $\ln (G D P \text { per capita })^{2}$ variable 
and its interaction with the democracy variable, dem $* \ln (G D P \text { per capita })^{2}$, to the model and test whether there is some limit at which the GDP per capita begins to affect excess returns and whether this is related to an effect of democracy. As the results in Appendix 2, Table 3 columns (1)-(4) show, although the coefficient values are higher, the original significant levels for the interactions of political risk and democracy level do not change much. We also find evidence that first the interaction of the democracy level and $\ln (G D P$ per capita $)$ increases local returns; but after a certain threshold level this effect begins to decline which is indicated by the negative coefficient of $\operatorname{dem} *$ $\ln (G D P \text { per capita })^{2}$

(iv) Estimation method. To study whether the estimation method has any effect on the results, we also estimate the results for system GMM with a robust one-step estimator. As shown in Appendix 2, Table 3, columns (5) and (6), the original results remain similar and their statistical significance even increases.

(v) Measure of democracy. Although, the definitions of polity and icrg democracy measures differ from one another, suggesting that the information in these measures is not identical, the large correlation between them indicates that they share many common features. To study whether our results are driven be the choice of our democracy variable we compute the average of these two of the democracy variables and use that as an alternative measure for democracy. The results are reported in Appendix 2, Table 3 columns (7)-(8). For pooled OLS the results remain similar as before but for system GMM the significance for democracy and the interaction terms is lost. This further stresses the importance of testing results with several democracy measures. 
Appendix 2, Table 3 here 
Appendix 2, Table 1: Robustness tests: Analysis period

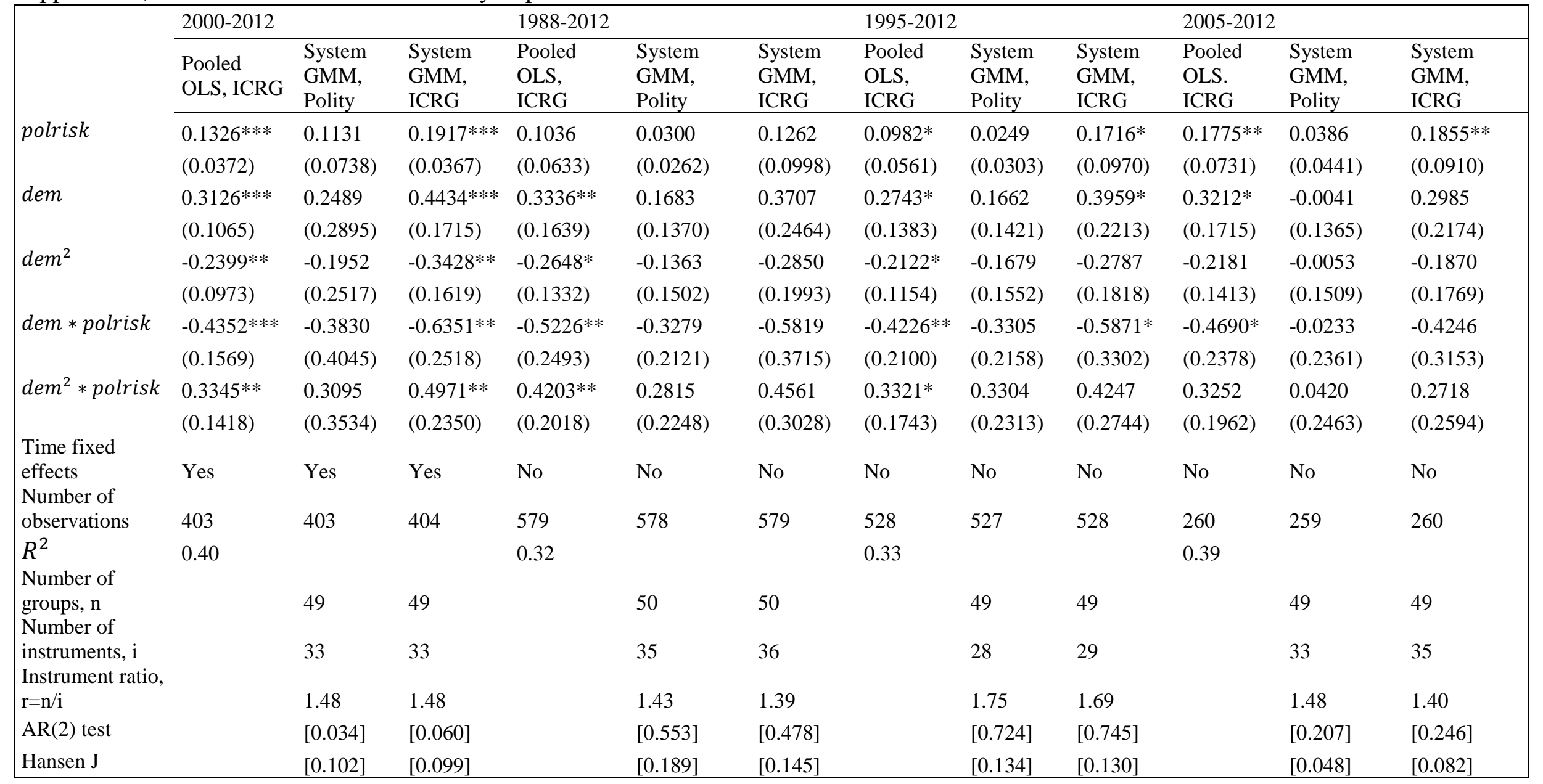

Notes: Heteroskedasticity robust standard errors in parenthesis. ***, $* *$ and $*$ denote statistical significance at 1,5 and $10 \%$ level, respectively. 
Appendix 2, Table 2: Robustness tests: Outliers

\begin{tabular}{|c|c|c|c|c|}
\hline & $\begin{array}{l}\text { Most politically } \\
\text { riskiest removed }\end{array}$ & $\begin{array}{l}\text { Least politically } \\
\text { riskiest removed }\end{array}$ & $\begin{array}{l}\text { Least democratical } \\
\text { removed }\end{array}$ & $\begin{array}{l}\text { Most democratical } \\
\text { removed }\end{array}$ \\
\hline \multirow[t]{2}{*}{ polrisk } & $0.2150 * * *$ & $0.2034 * * *$ & $0.2164 * * *$ & $0.1996 * * *$ \\
\hline & $(0.0387)$ & $(0.0494)$ & $(0.0444)$ & $(0.0630)$ \\
\hline \multirow[t]{2}{*}{ dem } & $0.4277 * * *$ & $0.4266^{* *}$ & $0.4364 * * *$ & $0.4103 * * *$ \\
\hline & $(0.1371)$ & $(0.1688)$ & $(0.1515)$ & $(0.1528)$ \\
\hline \multirow[t]{2}{*}{$\operatorname{dem}^{2}$} & $-0.3335 * *$ & $-0.3425 * *$ & $-0.3425 * *$ & $-0.3197 * *$ \\
\hline & $(0.1309)$ & $(0.1631)$ & $(0.1502)$ & $(0.1421)$ \\
\hline \multirow[t]{2}{*}{ dem $*$ polrisk } & $-0.6102 * * *$ & $-0.6179 * *$ & $-0.6144 * * *$ & $-0.5863 * *$ \\
\hline & $(0.1969)$ & $(0.2530)$ & $(0.2211)$ & $(0.2415)$ \\
\hline \multirow[t]{2}{*}{ dem $^{2} *$ polrisk } & $0.4833^{* * *}$ & $0.5072 * *$ & $0.4910 * *$ & $0.4689 * *$ \\
\hline & $(0.1860)$ & $(0.2447)$ & $(0.2179)$ & $(0.2132)$ \\
\hline Observations & 385 & 360 & 370 & 384 \\
\hline $\begin{array}{l}\text { Number of } \\
\text { groups, } \mathrm{n}\end{array}$ & 45 & 45 & 45 & 45 \\
\hline $\begin{array}{l}\text { Number of } \\
\text { instruments, i }\end{array}$ & 24 & 24 & 24 & 24 \\
\hline $\begin{array}{l}\text { Instrument ratio, } \\
\mathrm{r}=\mathrm{n} / \mathrm{i}\end{array}$ & 1.88 & 1.88 & 1.88 & 1.88 \\
\hline $\mathrm{AR}(2)$ test & [0.135] & {$[0.141]$} & {$[0.087]$} & [0.137] \\
\hline Hansen $\mathrm{J}$ test & {$[0.265]$} & [0.297] & {$[0.229]$} & [0.205] \\
\hline
\end{tabular}

Notes: Estimations are performed with System GMM using ICRG as the democracy measure.

Heteroskedasticity robust standard errors in parenthesis. $* * *, * *$ and $*$ denote statistical significance at 1,5 and $10 \%$ level, respectively. 
Appendix 2, Table 3: Robustness tests: Development, Estimation method and Democracy measure

\begin{tabular}{|c|c|c|c|c|c|c|c|c|}
\hline & \multicolumn{4}{|l|}{ Development } & \multicolumn{2}{|c|}{ One-step estimation } & \multicolumn{2}{|c|}{ Mean democracy } \\
\hline & $\begin{array}{l}\text { Pooled OLS, } \\
\text { Polity } \\
(1)\end{array}$ & $\begin{array}{l}\text { Pooled OLS, } \\
\text { ICRG } \\
(2)\end{array}$ & $\begin{array}{l}\text { System GMM, } \\
\text { Polity } \\
\text { (3) }\end{array}$ & $\begin{array}{l}\text { System GMM, } \\
\text { ICRG } \\
\text { (4) }\end{array}$ & $\begin{array}{l}\text { System GMM, } \\
\text { Polity } \\
\text { (5) }\end{array}$ & $\begin{array}{l}\text { System GMM, } \\
\text { ICRG } \\
(6)\end{array}$ & $\begin{array}{l}\text { Pooled OLS } \\
\text { (7) }\end{array}$ & $\begin{array}{l}\text { System GMM } \\
(8)\end{array}$ \\
\hline polrisk & $0.2095 * * *$ & $0.3198^{* * *}$ & $0.2243 * * *$ & $0.4005 * * *$ & $0.0768 * * *$ & $0.2270 * * *$ & $0.1728 * * *$ & $0.0637 * *$ \\
\hline & $(0.0753)$ & $(0.0724)$ & $(0.0663)$ & $(0.0587)$ & $(0.0224)$ & $(0.0434)$ & $(0.0571)$ & $(0.0250)$ \\
\hline dem & 0.1070 & -0.0507 & 0.2311 & 0.2323 & $0.1576^{*}$ & $0.5208 * * *$ & $0.3458 * *$ & 0.0647 \\
\hline & $(0.1562)$ & $(0.1973)$ & $(0.1937)$ & $(0.2074)$ & $(0.0872)$ & $(0.1150)$ & $(0.1564)$ & $(0.0932)$ \\
\hline $\mathrm{dem}^{2}$ & $-0.2616^{*}$ & $-0.4224 * * *$ & -0.3175 & $-0.5252 * * *$ & -0.1379 & $-0.4169 * * *$ & $-0.2596^{*}$ & -0.0567 \\
\hline & $(0.1427)$ & $(0.1271)$ & $(0.1991)$ & $(0.1578)$ & $(0.0918)$ & $(0.1081)$ & $(0.1333)$ & $(0.0985)$ \\
\hline dem $*$ polrisk & $-0.5878 * *$ & $-0.8569 * * *$ & $-0.6513 * *$ & $-1.0780 * * *$ & $-0.2709 * *$ & $-0.7494 * * *$ & $-0.4966^{* *}$ & -0.1169 \\
\hline & $(0.2567)$ & $(0.2228)$ & $(0.3259)$ & $(0.2561)$ & $(0.1364)$ & $(0.1728)$ & $(0.2228)$ & $(0.1488)$ \\
\hline dem $^{2} *$ polrisk & $0.4112 * *$ & $0.5829 * * *$ & $0.4888^{*}$ & $0.7496 * * *$ & $0.2464 *$ & $0.6090 * * *$ & $0.3800^{*}$ & 0.1121 \\
\hline & $(0.2040)$ & $(0.1799)$ & $(0.2804)$ & $(0.2257)$ & $(0.1392)$ & $(0.1588)$ & $(0.1895)$ & $(0.1510)$ \\
\hline $\ln (G D P$ per capita $)$ & $\begin{array}{l}-0.0218 * * \\
(0.0109)\end{array}$ & $\begin{array}{l}-0.1116 * * * \\
(0.0347)\end{array}$ & $\begin{array}{l}-0.0256 * * \\
(0.0103)\end{array}$ & $\begin{array}{l}-0.1112 * * * \\
(0.0405)\end{array}$ & & & & \\
\hline dem & & & & & & & & \\
\hline$* \ln (G D P$ per capita $)$ & $\begin{array}{l}0.0009 \\
(0.0006)\end{array}$ & $\begin{array}{l}0.0059 * * * \\
(0.0019)\end{array}$ & $\begin{array}{l}0.0010 * \\
(0.0006)\end{array}$ & $\begin{array}{l}0.0056^{* *} \\
(0.0023)\end{array}$ & & & & \\
\hline $\begin{array}{l}\ln (G D P \text { per capita })^{2} \\
\text { dem }\end{array}$ & $\begin{array}{l}0.0634 * * \\
(0.0286)\end{array}$ & $\begin{array}{l}0.1502 * * * \\
(0.0467)\end{array}$ & $\begin{array}{l}0.0410 \\
(0.0322)\end{array}$ & $\begin{array}{l}0.1110 * * \\
(0.0485)\end{array}$ & & & & \\
\hline$* \ln (G D P \text { per capita })^{2}$ & $\begin{array}{l}-0.0035^{* *} \\
(0.0017)\end{array}$ & $\begin{array}{l}-0.0082 * * * \\
(0.0027)\end{array}$ & $\begin{array}{l}-0.0020 \\
(0.0019)\end{array}$ & $\begin{array}{l}-0.0056 * * \\
(0.0028)\end{array}$ & & & & \\
\hline $\begin{array}{l}\text { Number of } \\
\text { observations }\end{array}$ & 403 & 404 & 403 & 404 & 403 & 404 & 403 & 403 \\
\hline$R^{2}$ & 0.37 & 0.35 & & & & & 0.34 & \\
\hline Number of groups, $\mathrm{n}$ & & & 49 & 49 & 49 & 49 & & 49 \\
\hline Number of instruments, & & & & & & & & \\
\hline i & & & 26 & 27 & 23 & 24 & & 23 \\
\hline Instrument ratio, $\mathrm{r}=\mathrm{n} / \mathrm{i}$ & & & 1.88 & 1.81 & 2.13 & 2.04 & & 2.13 \\
\hline $\mathrm{AR}(2)$ test & & & {$[0.057]$} & [0.089] & [0.111] & {$[0.126]$} & & {$[0.088]$} \\
\hline Hansen $\mathbf{J}$ & & & {$[0.149]$} & {$[0.215]$} & {$[0.184]$} & {$[0.176]$} & & {$[0.169]$} \\
\hline
\end{tabular}

Notes: Heteroskedasticity robust standard errors in parenthesis. ***, ** and * denote statistical significance at 1,5 and $10 \%$ level, respectively. 